Published in Review of international economics, 2016, pp.1-43 which should be cited to refer this work.

\title{
Examining the Export Wage Premium in Developing Countries*
}

\author{
Irene $^{\dagger}$ \\ Brambilla \\ UNLP
}

\author{
Nicolas ${ }^{\ddagger}$ \\ Depetris Chauvin \\ HEG-Geneva
}

\author{
Guido $^{\S}$ \\ Porto \\ UNLP
}

April 2016

\begin{abstract}
There are arguably potential wage gains from exports in developing countries. Export markets bring about opportunities for firms and successful exporting firms translate some of the benefits of exports to workers via employment and wage premia. Using comparable data for 61 developing and low-income countries, we document the prevalence of the export wage premia worldwide. With an extensive literature review, we identify four major drivers of the wage premia: exporting firms hire more skilled workers, utilize more sophisticated machines, buy higher quality material inputs, and are more productive than non-exporting firms. Our empirical analysis confirms the worldwide prevalence of these mechanisms and, furthermore, establishes a strong link to the estimated wage premia.
\end{abstract}

\footnotetext{
${ }^{*}$ We thank P. Garriga and L. Venturi for excellent research assistance. We have also benefitted from comments from seminar presentations at Universidad Nacional de La Plata, the University of Geneva, and DEGIT XX. All errors are our responsibility. We are grateful to the R4D program for Research on Global Issues for Development funded by Swiss National Science Foundation and the Swiss Development Cooperation.

†Universidad Nacional de La Plata, Departamento de Economia, Calle 6 e 47 y 48, La Plata 1900, Argentina; email: irene.brambilla@gmail.com

${ }^{\ddagger}$ Haute Ecole de Gestion de Geneve, University of Applied Sciences Western Switzerland; email: nicolas.depetris-chauvin@hesge.ch

${ }^{\S}$ Universidad Nacional de La Plata, Departamento de Economia, Calle 6 e 47 y 48, La Plata 1900, Argentina; email: guido.porto@depeco.econo.unlp.edu.ar
} 


\section{Introduction}

Export markets bring gains to the domestic economy and can become an engine for development in low income countries. In particular, the evidence shows that exporting firms pay higher wages and hire more workers than non-exporters. This is due to the combination of special requirements of the act of exporting, such as quality upgrades or exporting services, and some inherent attributes of firms, such as productivity, technology, and efficiency (Matsuyama, 2007; Verhoogen, 2008). In this scenario, exporting brings up enhanced opportunities for firms in world markets, and these opportunities can be successfully exploited if firms have, or develop, the needed attributes to become efficient world producers. In turn, this process has implications for employment and wages and, in consequence, the whole mechanism allows those world export opportunities to be transmitted to the local economy. In the end, the benefits from globalization can be realized not only at the firm level (e.g., in terms of profits) but also at the worker level (e.g., in terms of wages and employment).

Our goal in this paper is to assess these arguments. We want to study whether exporting firms do pay higher wages, focusing in particular on lower income countries, and to investigate some of the operating mechanisms. To this end, we build on a literature review that identifies major theories and hypothesis related to exports and wages. In this review, we find that export markets demand high quality products and that the production of high quality products requires high-quality, skilled labor, high-quality, imported inputs, high-quality, sophisticated machine, and high-quality, productive firms. Then, we use comparable micro-data from the Enterprise Surveys to quantitatively document the wage premia paid by exporting firms in 61 developing and low-income countries and we document the role of product quality, labor quality, input quality, technology and productivity. We find strong evidence of a wage premium among exporting firms and we provide strong support for the operating mechanisms advocated by the literature. In our sample of 61 countries, these mechanisms explain most of the wage premia.

The paper is organized as follows. In section 2, we describe and use firm-level micro data to estimate the wage exporter premia. In section 3, we do a comprehensive literature 
review of several dozen papers from the literature and we provide evidence of some of the mechanisms at play behind those premia. In section 4 , we assess the role of these mechanisms in explaining the wage premia. Section 5 concludes.

\section{Exporting Firms and the Wage Premium}

The aim of this section is to establish empirically the main premise of this study, namely that exporting leads to gains in wages. Since the literature mostly provides estimates of wage export premia in middle-income and developed countries, we are particularly interested in determining whether this observation holds for developing and low-income countries too. This is an important contribution of our paper.

\subsection{The Data}

The basic set of stylized facts concerning exporting firms and wages is derived here using comparable data from the Enterprise Surveys. An Enterprise Survey is a firm-level survey of a representative sample of an economy's private sector. The surveys cover a broad range of business environment topics including access to finance, corruption, infrastructure, crime, competition, and performance measures. The Enterprise Surveys provide the world's most comprehensive firm-level data for low income countries. The Enterprise Surveys project is jointly led by the World Bank and various partners, such as the European Bank for Reconstruction and Development, the Inter-American Development Bank (IDB), COMPETE Caribbean, and the UK's Department for International Development (DFID).

In every country, there is a unique and consistent definition of the universe of the survey. This universe can be described as the non-agricultural formal, private economy and it includes manufacturing, retail, other services, IT, construction, and transport. All firms with 5 employees or more are included. Samples are stratified by industry, size, and geographical regions. The number of strata is defined according to the size of the economy. For large and very large economies between 2 to 6 manufacturing sectors are selected to be surveyed with samples large enough to allow for sector analysis (productivity). Retail is also 
single out as a stratum on its own. The rest of the economy is allocated into two additional strata: rest of manufacturing, and the rest of the economy (including construction, transport, and other services). Medium size economies are stratified only into manufacturing, retail and the rest of the economy. Small economies are stratified into manufacturing and services and usually their sample size is 150 firms.

Special emphasis is placed on the quality of the information. Experience shows that this is highly correlated to the length of the questionnaire which also affects the response rate. Consequently, the questionnaire is designed to not take longer than 1 hour to complete. A unique global questionnaire is used across all regions. To incorporate regional interests, 60 variables are allocated to reflect regional characteristics, provided that the questions follow the general format of the global questionnaire. Regional questions can be distributed across the questionnaire or ideally into modules about topics of interest for the region. Two versions of the questionnaire are used to facilitate implementation and reduce the duration of the interview. There is a core minimum number of questions that apply to every establishment. The services version adds some questions specific for the retail sector and other services sectors; the manufacturing version adds questions specific to the sector and some basic accounting information to estimate productivity at the establishment level.

Table 1 lists the countries covered in the analysis as well as some basic information on export exposure. The data cover most developing countries, and many low-income countries, especially in Africa. As it can be seen in column 3 of Table 1, the Enterprise Survey data uncover a significant exposure to exports. On average, worldwide, 34 percent of firms participates in exports. The fraction of exporting firms is 36 percent in Latin America and Asia, 32 percent in Europe and only 28 percent in Africa. There is a lot of dispersion, even within continents. For instance, the fraction of exporters is 71 percent in Macedonia, and 17 percent in Russia; 55 percent in Argentina, and 26 percent in Nicaragua; 62 percent in Thailand, and 14 percent in Kazakhstan. In Africa, the fraction of exporters ranges from as high as 61 percent in South Africa and 60 percent in Morocco, to 3 percent in Nigeria, 5 percent in Burundi, or 7 percent in Ethiopia.

It is noteworthy that the intensity of exports also varies a lot across countries, and not 
necessarily as export participation does. We define export intensity as the share of exports in total sales for exporting firms. Worldwide, the average exporter ships 53 percent of its sales abroad. The highest export intensity is computed in Asia, 69 percent. In Africa, the

average exporting firm exports 53 percent of its sales, the worldwide average, but the share of exporting firms is the lowest. Latin American exporters ship on average 34 percent of their sales abroad, and the corresponding figure for Europe is 46 percent.

In Table 2, we provide basic summary statistics for the main variables used in this study. For all variables, the data show significant heterogeneity and, to simplify the exposition, we briefly discuss world averages relative to regional averages. For instance, the average world ratio of skilled to unskilled workers is 1.64 (column 1). This ratio is 3.17 in Europe, 1.26 in Latin America, 1.67 in Africa, and 1.65 in Asia. The average capital to labor ratio is 8.59 in the world, 9.97 in Europe, 8.84 in Latin America and Africa and 8.08 in Asia (column 2). On average, 22 percent of firms has ISO-certified products (column 3). Around 51 percent of firms is an importer (column 4) and the share of imported input use is 27 percent (column 5). Around 12 percent of firms has at least some degree of foreign ownership, while 9 percent has majority foreign ownership (columns 6 and 7). In column 8, we report measures of total factor productivity. The highest TFP is estimated in Europe, followed by Latin America, Asia and, finally, Africa.

\subsection{The Wage Premium}

The starting point of our quantitative analysis is the exploration of the correlation between exports, exporting firms, and wages. Since the firm-level Enterprise Survey is a cross-section, the regression model is

(1) $\quad \ln w_{i j}=\delta E_{i j}+\phi_{j}+u_{i j}$

where $\ln w_{i j}$ is $\log$ of the average wage in firm $i$ in industry $j, E_{i j}$ is a measure of exporting status, $\phi_{j}$ is an industry fixed effect and $u_{i j}$ is an error term. In (1), the exporting status of firm $i$ is measured with a dummy (equal to 1 for exporting firms) so that the coefficient 
of interest, $\delta$, is interpreted as the wage exporter-premium. It should be noted that the regression model in equation (1) can only uncover (unconditional or conditional) correlations, and that no causality can be inferred.

We explore the wage premium in Table 3. We estimate different wage premia for each country in our data as well as for countries within regions (continents) and for the developing world as a whole. This is important in order to quantify worldwide wage premia and, in particular, wage premia for the poorest countries in the world - countries for which evidence on exporter premia is missing entirely.

On average across developing countries, exporting firms pay 31 percent higher wages than non-exporters. There is a fair degree of heterogeneity across regions. The premia are 20 percent in Europe, 22 percent in Africa, 38 percent in Latin America, and 30 percent in Asia. As expected, there is a lot of cross-country heterogeneity as well. For instance, the highest wage premia are estimated in Moldova (67 percent), Côte d'Ivoire (77 percent), Peru (52 percent), Brazil and Uruguay (51 percent), and the Philippines (62 percent). The lowest premia (which often are not statistically significant) are estimated in Hungary (9 percent), Ghana (6 percent), Kenya and Zimbabwe (7 percent), Paraguay (6 percent), and India (5 percent).

To some extent, these cross-country differences are due to differences in industry coverage. In fact, the surveys may target different industries in different countries and in different time periods. To assess this, we identify a group of "selected" industries that are covered in all Enterprise Surveys. These are Textiles, Garment, Food, Beverages, and Metals and Machinery. As we report in column 2 of Table 3, we find that the estimated premia is in general robust.

While we study the main determinants of these premia below, it is important at this moment to explore whether our findings can be affected by firm ownership. In many developing countries, exporting firms are owned by foreign companies and this may affect wages and employment. In column 3, however, we find, overall, similar patterns of wage exporting premia as before. For instance, the average worldwide premium is 25 percent (as opposed to 31 percent in column 1). The premia are generally attenuated (relative to the 
regressions without controlling for ownership): for Europe, the premium declines from 20 to 17 percent; in Africa, it declines from 22 to 18 percent; in Latin America, from 38 to 33 percent; and, in Asia, from 30 to 21 percent. This happens because foreign firms pay higher wages. Nevertheless, conditional on this, there is still evidence of a sizeable wage exporting premium. ${ }^{1}$

Finally, to put these estimates into better context, we compare them with the main findings in the literature. In fact, the finding of an export wage premium is actually not surprising. It is a very well-documented fact since the seminal work of Bernard and Jensen (1995), Bernard and Jensen (1999) and Bernard and Wagner (1997). A large literature follows Bernard and Jensen's methodology (to different degrees) and establishes the existence of export premium in wage regressions. Most of these studies, however, cover middle-income or high-income countries. Specifically, see Bernard and Jensen (1995), Bernard and Jensen (1999), Bernard and Jensen (2004) for the U.S. Their estimated wage premia range from 7 to 14 percent. For Germany, Bernard and Wagner (1997) find wage premia of 7 percent, Arnold and Hussinger (2005) of 24 percent, and Baumgarten (2013) of 22.3 to 29.8 percent. For Taiwan, Aw and Batra (1999) and Liu et al. (1999) report wage premia of 30 percent for non-production workers, 14 percent for production workers, and around 15.5 percent for the average worker. Also for Taiwan, Tsou et al. (2002) find wage premia of 18.6 to 23.8 percent. Greenway and $\mathrm{Yu}$ (2004) estimate wage premia in the UK ranging from 4.5 to 6.4 percent. In Korea, the wage premium is around 12 percent (Hahn, 2004); in Sweden, it is 1.5 percent for unskilled workers and 7 percent for skilled workers (Hansson and Lundin, 2004); in Slovenia, it is around 16 percent (De Loecker, 2007); in Spain, it is around 25-35 percent (Farinas and Martin-Marcos, 2007).

While, overall, our estimates in Table 3 are in line with this evidence, it is difficult to elaborate on this comparison because of major differences in country coverage. There are, nevertheless, a few instances in the literature that allow for a more meaningful comparative

\footnotetext{
${ }^{1}$ It is important to note that we are estimating these premia using cross-sectional data collected at, often, different years. It might consequently be possible that these wage premia are capturing differences in business cycles across countries. These factors can contribute to the heterogeneity in wage premia observed in the data. For these reasons, we focus on averages rather than country-specific estimates and, as we explain below, on the underlying mechanisms.
} 
analysis. Zhou (2003), for instance, examines the case of Mexico and finds wage premia of around 7 to 9 percent. Our estimate for Mexico is larger, about 40 percent. Isgut (2001) studies the Colombian case and finds a wage premia of 40-50 percent for managers and 9-16 percent for blue-collar workers. Our estimate for Colombia is 42 percent. In Chile, Alvarez and Lopez (2005) report wage premia of 15 percent for production workers, 28 percent for non-production workers and 21 percent for the average worker. Our estimate for Chile is 26 percent. For Latin America as a whole, our estimated average premium ranges from 33 to 38 percent.

By exploiting the data from the Enterprise Surveys, we are able to produce estimates of the wage premium for a much wider set of countries. We arguably fill a gap in the literature. A nice paper, which is close to ours, is Van Biesebroeck (2005), who explores nine African countries: Burundi, Cameroon, Côte d'Ivoire, Ethiopia, Ghana, Kenya, Tanzania, Zambia and Zimbabwe. This paper reports an average African wage exporting premia of 40 percent. Our average estimate, across several other countries, is smaller, around 22 percent.

\section{Mechanisms}

For both analytical purposes and for policy purposes, it is important to understand the mechanisms by which the link between exports, wages and employment operates. To explore this issue, we proceed as follows. First, we do a comprehensive literature review to identify, both theoretically and empirically, the main mechanisms. These turn out to be skilled labor utilization, technology sophistication, imported input use, and productivity. Second, illustrate formally the literature by introducing a simple model that captures, in a cohesive way, those four major mechanisms.

\subsection{Identifying Some of the Main Mechanisms}

The literature has postulated several hypotheses to explain the link between exporting and the wage (and employment) premium. Originally, two theories stood out (Roberts and Tybout, 1997; Clerides, Lach, and Tybout, 1998). One theory argues that firms self-select 
into exporting. Consequently, "better" firms becomes exporters and, jointly, perform better. This better performance manifests itself with the payment of a wage premium and the hiring of more workers, among other features (such as productivity, input use, technology adoption; more on this below). An elaboration of this idea is the conscious self-selection theory, whereby self-selection is a conscious decision of firms that become "better" (e.g., become more productive) with the intended purpose of becoming exporters (Alvarez and Lopez, 2005; Lopez, 2009). The other theory postulates a learning-by-exporting process. Firms become exporters and later become "better," paying higher wages, employing more workers, and so on. Both theories imply a correlation between exports and firm productivity. The evidence, however, tends to support a theory of self-selection more than a theory of learning-by-exporting. A widespread (but not universal) interesting finding of this literature is that, while it is clear that good firms become exporters, it is less clear that exporters remain significantly better than non-exporters (Bernard and Jensen, 1995; Bernard and Jensen, 1999; Bernard and Wagner, 1997). ${ }^{2}$

In this paper, our aim is to take further steps into disentangling the underlying mechanisms. Our starting point is thus the well-established fact that exporters are more productive than non-exporters and, following Melitz (2003), that this productivity advantage translates into higher wages and employment. Our goal in what follows is to uncover some of the mechanisms behind the main productivity channel.

There are many reasons why more productive exporters hire more workers and, especially, why they pay higher wages. A key reason is that the production of goods for export requires skilled labor. Skilled labor is needed because exporting requires quality upgrades, as in Verhoogen (2008) or because the act of exporting involves operational services, as in Matsuyama (2007). ${ }^{3}$ Both the provision of quality and the production of exporting

\footnotetext{
${ }^{2}$ See the review in Wagner (2007). Key paper in this literature are Alvarez and Lopez (2005), Hansson and Lundin (2004), Greenaway and Yu (2004), Serti and Tomassi (2008), Isgut (2001), Delgado, Farinas and Ruano (2002), Fryges and Wagner (2008), Arnold and Hussinger (2005), Frias, Kaplan and Verhoogen (2009), Kandilov (2009), De Loecker (2007), Wagner (2002), Park, Yang, Shi, and Jiang (2010), Marin (1992).

${ }^{3}$ Using aggregate product-level bilateral trade data, Hallak (2006) is one of the first authors to document the positive correlation between export unit values and the level of income of the country of destination. More recent studies, such as Baldwin and Harrigan (2011) and Johnson (2012), also find positive correlations between export unit values and the income of the destination country. Using firm-level data, Manova and
} 
services are skilled-intensive activities. As a result, firms that choose to export need to hire proportionately more skilled labor and pay their high-skilled workers a wage premium. Exporters can afford to do that because exports markets pay, in turn, a premium for their products. Another reason why exporters pay higher wages is a complementarity between the choice of technology of production used in exporting and the skilled level needed to use those technologies. Yeaple (2005) and Acemoglu and Zilibotti (2001) are examples. ${ }^{4}$

There is a large empirical literature linking skill utilization and exports. Bernard and Jensen (1997) document that increases in employment at exporting plants contribute to the observed increase in relative demand for skilled labor in manufacturing in the U.S. Moreover, exporters account for almost all of the increase in the wage gap between high-and low-skilled workers. Munch and Skaksen (2008) study the link between the education level of a firm workers, its export performance and the workers wages. Using matched worker-firm panel data, these authors find that firms with high export intensities do indeed pay higher wages and use more skilled labor. However, an interaction term between export intensity and skill intensity has a positive impact on wages and it absorbs the direct effect of the export intensity. This means that the export wage premium found in the data accrues to workers in firms with high skill intensities. Verhoogen (2008) uses the Mexican devaluation of 1994 as an exogenous change in exports. He finds that firms that were more intensively affected by this "export" shock paid higher wages and that this was in part due to an increase in the composition of skilled employment needed to upgrade product quality in Mexican exports to the U.S. Bustos (2014) studies the experience of Argentine firms in the face of enhanced export opportunities to Brazil and confirms that the reduction in Brazil's tariffs induces the most productive Argentine firms to upgrade skills. In fact, she documents that one third of the increase in the relative demand for skills can be attributed to the reduction in Brazil's tariffs. There are many other papers linking exports to skill utilization. Serti, Tomasi and

Zhang (2012) show that Chinese exporting firms do indeed charge higher prices in richer markets. Similar evidence is reported by Bastos and Silva (2010), for the case of Portuguese exporters, and Görg, Halpern and Muraközy (2010), for the case of Hungarian exporters.

${ }^{4}$ Yet another reason is profit-sharing. Exporters make higher profits and, because of efficiency wages, firms share part of those higher profits with workers. See Egger and Kreickemeier (2009), Egger and Kreickemeier (2010) and Egger and Kreickemeier (2012) for a theoretical approach and Amiti and Davis (2011) for empirical evidence for Indonesia. 
Zanfei (2010) investigate the Italian manufacturing industry and Söderbom and Teal (2000) focus on Ghana.

A different strand of literature provides evidence in support for a quality provision mechanism in exports. Schott (2004) explores U.S. import unit values and reports higher unit values for varieties originating in capital- and skill-abundant countries. Moreover, exporting countries that become more skill- and capital-abundant with time experience increases in unit values relative to other exporters. He also finds that richer countries tend to export higher quality products. Hummels and Klenow (2005) show that quality differentiation is needed to explain differences in unit values and show that these unit values positively correlate with per capita income of the exporting country. Hallak (2010) documents that trade is more intense among countries with similar income per capita - the Linder hypothesis. Caron, Fally, and Markusen (2014) establish a positive correlation between the income elasticity of a good and its skilled-labor intensity. This implies that richer countries demand and produce higher quality goods and, as a consequence, trade between rich countries is more intense than trade between rich and poor countries (especially in higher quality goods).

Exporters may pay higher wages (on top of the skilled labor utilization mechanism) because of complementarities with technology upgrades. Bustos (2011) provides evidence on the link between exports and technology upgrading in Argentina after MERCOSUR. Her empirical analysis reveals that firms in industries facing higher reductions in Brazil's tariffs (main MERCOSUR partner for Argentine firms) increase investment in technology faster, especially for middle-upper and high-productivity firms. Lileeva and Trefler (2010) study the experience of Canadian firms and their exports to the U.S. They find that those lower-productivity Canadian plants that were induced by the tariff cuts to start exporting engaged in more product innovation and had high adoption rates of advanced manufacturing technologies. In contrast, they find no effects for higher-productivity plants. An important related paper is Aw, Roberts and $\mathrm{Xu}$ (2011). This paper estimates a dynamic structural model of a producer's decision to invest in R\&D and export, allowing both choices to endogenously affect the future path of productivity. Using plant-level data for the Taiwanese electronics industry, both activities are found to have a positive effect on 
the plant's future productivity. This in turn drives more plants to self-select into both activities, contributing to further productivity gains. Simulations of an expansion of the export market are shown to increase both exporting and R\&D investment and generate a gradual within-plant productivity improvement.

The literature has pointed out that the production of export goods (e.g., products of higher quality) often requires high quality inputs (besides high quality labor, as above). In general, in developing countries, higher quality inputs are imported. If there is, as suggested in the literature, a complementarity between the use of higher-quality inputs and the use of higher-quality labor, then this is another mechanism underlying the wage export premium. This mechanism can be interpreted as an extension of the idea advanced by Verhoogen (2008). Kugler and Verhoogen (2012) elaborate on this "quality-complementarity" hypothesis and show that input quality and plant productivity are complementary in generating output quality. The empirical results for Colombia indicate that higher productivity firms (which are more likely to be exporters) charge more for their outputs and pay more for their material inputs.

The empirical evidence on the link between imported inputs and wages is indirect. Bas (2012) looks at the relationship between changes in input tariffs and within-firm changes in export status. Using detailed firm-level data from Argentina, she finds that the probability of entering the export market is higher for firms producing in industries that have experienced greater input tariff reductions. Bas and Strauss-Kahn (2011) use firm import data at the product (HS6) level in France to confirm that access to new varieties of inputs increase productivity, and thereby exports, through better complementarity of inputs and transfer of technology. Feng, Li and Swenson (2012) look at Chinese manufacturing firms following the country accession to the WTO. Their results show that firms that expanded their intermediate input imports expanded the volume of their exports and increased their export scope. 


\subsection{Theoretical Model}

To better organize our discussion, we develop here a simple model that captures the mechanisms outlined in the review. The goal is to lay out a theoretical framework to formalize the intuitions provided by the empirical results. The model is a simple partial equilibrium model. We introduce the demand and production structure and we study optimal firm decisions. In the process, we describe how the four mechanisms work.

Firms operate in a monopolistic competition framework. Goods are differentiated in quality. A variety $j$ has quality $\theta_{j}$ and price $p_{j}$. As in Verhoogen (2008) and Brambilla, Lederman, and Porto (2012), we work with logit demands. Firms can sell domestically $d=h$ (home) or abroad $d=e$ (export). Aggregate demand in market $d$ is:

(2) $x_{j}^{d}\left(p_{j}^{d}, \theta_{j}^{d}\right)=\frac{M^{d}}{W^{d}} \exp \left(\alpha^{d} \theta_{j}^{d}-p_{j}^{d}\right)$,

where $\alpha^{d}$ captures quality valuation and we assume that $\alpha^{e}>\alpha^{h}$ because export markets are willing to pay a premium for a good of a given quality. In (2), $M^{d}$ is the number of consumers in market $d$, or market size, and $W^{d}$ is an index that summarizes the characteristics of all available products in that market (i.e. $W^{d}=\sum_{d \in Z^{d}} \exp \left(\alpha^{d} \theta_{z}^{d}-p_{z}^{d}\right)$, where $Z^{d}$ is the set of available products).

Firm $j$ chooses the quality $\theta_{j}$ of the good and its selling price $p_{j}$ to maximize profits:

$$
\pi_{j}=\left[p_{j}-c_{j}\left(\theta_{j}\right)\right] x\left(p_{j}, \theta_{j}\right)-F,
$$

where $c_{j}\left(\theta_{j}\right)$ is the marginal cost of production, that depends on quality, with $c_{j}^{\prime}\left(\theta_{j}\right)>0$ and $c_{j}^{\prime \prime}\left(\theta_{j}\right)>0 . F$ is a fixed cost of production or of entering a market, which for simplicity is assumed to be the same across firms. As in Verhoogen (2008), we assume that firms can choose prices $p_{j}^{d}$ and quality $\theta_{j}^{d}$ for the domestic and the export market separately. The first order conditions for profit maximization are:

(4) $p_{j}^{d}=1+c_{j}\left(\theta_{j}^{d}\right)$, 
(5) $\quad \alpha^{d}=\frac{c_{j}^{\prime}\left(\theta_{j}^{d}\right)}{p_{j}^{d}-c_{j}\left(\theta_{j}^{d}\right)}$.

The intuition is straightforward. Firms charge a constant markup over marginal costs (equation (4)) and, given the optimal markup, optimal quality in a given market requires equating the marginal costs of quality provision with the quality valuation $\alpha$ (equation (5)). Note that since $\alpha^{e}>\alpha^{d}$, we have that $\theta_{j}^{e}>\theta_{j}^{d}$ and $p_{j}^{e}>p_{j}^{h}$. Since export markets value quality more, firms optimally sell higher quality products at higher prices abroad.

To explore the mechanisms in more detail, we need to describe the marginal cost function $c_{j}\left(\theta_{j}\right)$. We adopt a unifying framework based on Johnson (2012), Crino and Epifani (2012), Hallak and Sivadasan (2013), Flam and Helpman (1987), Hummels and Klenow (2005), Verhoogen (2008), Bastos, Silva and Verhoogen (2014), Brambilla, Lederman, and Porto (2012), Feenstra and Romalis (2012), and Kugler and Verhoogen (2012). To produce quantity and quality, a firm utilizes three production factors: labor, (imported) material inputs, and capital or technology. These factors are combined with the inherent attributes of a firm, which we call productivity. The technology to produce physical quantity differs from the technology to produce quality.

The production of one unit of physical output requires 1 unit of labor, 1 unit of imported material inputs, and 1 unit of capital/technology. This is a fixed-coefficient production function. All these three production factors are heterogeneous in quality. Workers are heterogeneous in skills or ability, $S$. Imported materials differ in quality $M$, and capital or technology differs in their "sophistication" $K$.

The quality of the inputs is instead relevant in the production of the quality of the output (the "quality-complementarity" hypothesis of Kugler and Verhoogen, 2012). Thus, for example, a higher ability worker can produce, ceteris paribus, 1 unit of physical output, but of a higher quality $\theta$. To model quality production, firms combine factors with "capability" or "caliber" $\lambda$ (Kugler and Verhoogen, 2012; Hallak and Sivadasan, 2013) as follows:

$$
\theta_{j}=\lambda_{j}\left(K_{j}\right)^{\sigma^{K}}\left(M_{j}\right)^{\sigma^{M}}\left(S_{j}\right)^{\sigma^{S}}
$$

where $\sigma^{K}>0, \sigma^{M}>0, \sigma^{S}>0$. This is a standard Cobb-Douglas production function and 
it implies some degree of complementarity among capability, the quality or sophistication of capital, the quality of (imported) material inputs and skills. Since we are interested in wages, it is important to highlight that this production function implies that firms with higher $\lambda$, higher $K$, and higher $M$ are more efficient in using skilled labor in the generation of quality. More generally, equation (6) delivers a positive relationship between the production of quality $\theta_{j}$ and the quality of inputs $S_{j}, M_{j}$ and $K_{j}$.

To attract higher skilled workers (to produce higher quality), firms face an upward sloping wage scheduled as in Verhoogen (2008). We work with a simple functional form

$$
\text { (7) } \quad S_{j}=\left(w_{j}^{S}\right)^{\xi^{S}}
$$

where $w_{j}^{S}$ is the wage rate offered to skills $S_{j}$ and $\xi^{S}>0$ governs the responsiveness of skills to the offered wage. Equation (7) can be interpreted as a reduced-form representation of an efficiency-wage model or a profit sharing model. We adopt similar factor-price schedules for technology, $K_{j}=\left(w_{j}^{K}\right)^{\xi^{K}}$, and material inputs $M_{j}=\left(w_{j}^{M}\right)^{\xi^{M}}$, where $w_{j}^{K}$ and $w_{j}^{M}$ are the prices for technology and material inputs and $\xi^{K}, \xi^{M}>0$.

For a firm, the cost of producing one unit of output of quality $\theta_{j}$ is the cost of hiring one worker of skill $S_{j}$ at the wage $w_{j}^{S}$, one unit of capital with sophistication $K_{j}$ at price $w_{j}^{K}$ and one unit of material inputs with quality $M_{j}$ at price $w_{j}^{M}$. As in Verhoogen (2008), we assume that firms run separate production lines for different qualities. Separability in production allows firms to make independent decisions of entry, quality choice, and price to each market. As in all this literature, firms are heterogeneous in capability/caliber $\lambda$.

To work out the full solution of the model, note that firms jointly choose the quality of capital, labor and material inputs to minimize $\operatorname{costs} c=w^{S}+w^{K}+w^{M}$, subject to the quality production function (6) and the wage schedules (7). The optimal choice of quality is (8) $\quad \theta_{j}^{*}=(\alpha)^{\frac{a}{1-a}} \lambda_{j}^{\frac{1}{1-a}} J$,

where $a=\xi^{S} \sigma^{S}+\xi^{K} \sigma^{K}+\xi^{M} \sigma^{M}$ and we assume that $a<1$ (to get an interior solution for $\theta$ ) and $J=\left[\left(\xi^{S} \sigma^{S}\right)^{\xi^{S} \sigma^{S}}\left(\xi^{K} \sigma^{K}\right)^{\xi^{K} \sigma^{K}}\left(\xi^{M} \sigma^{M}\right)^{\xi^{M} \sigma^{M}}\right]^{1 /(1-a)}$. The solutions for optimal labor 
quality $S$, material inputs quality $M$ and capital sophistication $K$ are

$$
\begin{aligned}
& S_{j}^{*}=\left(\xi^{S} \sigma^{S}\right)^{\xi^{S}}(\alpha)^{\frac{\xi^{S}}{1-a}}\left(\lambda_{j}\right)^{\frac{1}{1-a}} J^{\xi^{S}} \\
& M_{j}^{*}=\left(\xi^{M} \sigma^{M}\right)^{\xi^{M}}(\alpha)^{\frac{\xi^{M}}{1-a}}\left(\lambda_{j}\right)^{\frac{1}{1-a}} J^{\xi^{M}},
\end{aligned}
$$

and

$$
K_{j}^{*}=\left(\xi^{K} \sigma^{K}\right)^{\xi^{K}}(\alpha)^{\frac{\xi^{K}}{1-a}}\left(\lambda_{j}\right)^{\frac{1}{1-a}} J^{\xi^{K}}
$$

Ultimately, the choices of input quality are a function of firm features such as productivity or caliber $\lambda$. As in all the literature, we assume firms face a fixed costs of entering the domestic market and an additional fixed cost of entering the foreign market. This defines two productivity cutoff $\lambda_{\min }$ and $\lambda_{\text {exp }}$ so that firms with productivity $\lambda<\lambda_{\text {min }}$ cannot afford to enter any market, firms with productivity $\lambda_{\min }<\lambda<\lambda_{\exp }$ produce for the domestic market, and firms with productivity $\lambda>\lambda_{\exp }$ produce for both the domestic and the export markets. In the upper-left graph of Figure 1, we highlight the average quality produced by firms with different productivities. As it can be seen, firms that enter the export market produce higher average quality. At low productivity levels, average quality tracks the quality demanded at the domestic market. There is a discrete jump at the cutoff $\lambda_{\text {exp }}$, and then average quality is just the average of the quality demanded domestically and abroad.

We can also see in Figure 1 that exporters hire more skilled labor, purchase more and better material inputs and adopt a higher sophistication of technology. We plot the optimal choice of $S$ (upper-right panel), $K$ (lower-left panel) and $M$ (lower-right panel) as a function of $\lambda$ for the domestic market and for the foreign market. As with optimal quality, the average skill increases in $\lambda$ as exporters hire, on average, more skilled workers. Similar statements can be made for the cases of material inputs and capital sophistication.

We now turn to the evidence provided by our regression analysis using the Enterprise Surveys. 


\subsection{Skill Utilization}

To study whether exporters demand relative more skilled over unskilled workers than non-exporters, we adopt the following variant of regression model (1)

(12) $s_{i j}=\delta E_{i j}+\phi_{j}+u_{i j}$

where now the dependent variable $s_{i j}$ is some measure of the utilization of skilled labor relative to unskilled labor. All other variables are defined as above.

Our main results are reported in Table 4. In column 1, we measure the correlation between exporting and the ratio of skilled to unskilled production employment. ${ }^{5}$ This correlation is always positive and statistically significant across developing countries. Worldwide, for instance, an exporter has 0.91 more skilled workers per unskilled worker, indicating that exporters hire roughly one skilled worker more, per unskilled workers, than non-exporters. This result holds on average in each continent as well. In Eastern Europe, the coefficient is 1.99, in Africa, 0.74, in Latin America, 0.65, and in Asia, 1.04.

In column 2 , the dependent variable is the share of the work-force with completed high-school. This information is not available for all surveys, and consequently our analysis is less detailed than before. Nevertheless, we confirm that exporting is positively correlated with this measure of skill utilization. Worldwide, on average, the proportion of the workforce of an exporting firm that has completed high-school is 4 percent higher than for non-exporters. It is interesting to note that the share of completed high-school workers is actually 5 percent higher in Europe, Latin America and Asia, while the correlation is not statistically significant in Africa.

In columns 3 and 4 , we investigate whether exporters demand specific skills from high-rank employees. Concretely, we look first at the quality (i.e., education) of managers. In column 3, we find that, on the average (worldwide) exporting firm, managers are 17 percent more likely to have College Education that at a non-exporter. This correlation is strong statistically and very robust across continents. In Latin America, for instance, the

\footnotetext{
${ }^{5}$ According to these definition, skills can be acquired formally in colleges, universities or technical schools, or on the job.
} 
coefficient is 0.25, in Asia, 0.13, and in Africa 0.19. In column 4, we explore the probability that a manager has Post-Graduate Education. We find that, on average, the probability that the manager of an exporting firm has a Post-Graduate degree is 12 percent higher compared to non-exporters. This correlation also holds in Latin America (18 percent), Asia (8 percent), and Africa (13 percent).

\subsection{Sophistication of Technology}

To investigate the premia in machine sophistication, the regressions are the same as before, except that we change the dependent variables. Results are also reported in Table 4. In column 5, we correlate export status with the firm's capital labor ratio. We find that this correlation is positive and statistically strong everywhere (on average, in Europe, in Latin America, in Asia, and in Africa.). In column 6, we look at the correlation with the probability

of having ISO-certified product, and we find that it is much higher at exporting firms than at non-exporting firms. Worldwide, on average, exporters are 24 percent more likely to have ISO certification than non-exporters. The link appears stronger in Asia (27 percent) and Latin America (16 percent) than in Africa (20 percent) or Europe (21 percent). But the association is always statistically very significant.

For a subset of countries, we also have information of the adoption of new technologies (column 7) and R\&D spending (column 8). Exporters are 11 percent more likely to incorporate new technologies than non-exporters. Similarly, R\&D spending is 5 percent higher at exporting firms, on average.

\subsection{Imports and Imports of Intermediate Inputs}

The Enterprise Surveys allow us to explore the role of better inputs because firms are asked whether they purchase inputs from aboard. In general, for developing countries, imported inputs are of higher quality than domestic inputs (Kugler and Verhoogen, 2012; Manova and Zhang, 2012). We can thus study whether exporters tend to purchase imported inputs, and whether they tend to spend a higher fraction of resources on imported inputs. The regression model is the same as before, with changed dependent variables. 
Results are in Table 5. We first investigate whether exporters are more likely to be importers too (Bernard, Jensen, Redding, and Schott, 2007). They indeed are. In column 1, we find that an exporter is 27 percent more likely to be an importer as well. This is a very strong and robust correlation. It is observed in Europe (20 percent premium), Latin America (22 percent premium), Asia and Africa (31 percent premium). In column 2, we examine if this correlation operates for imports of intermediate inputs. It does, also very strongly. We look at the correlation between exporting and the share of inputs used by the firm that are imported. On average, exporters have 14 percent higher imported inputs than non-exporters. This correlation is very robust. A European exporter has 14 percent higher imported inputs, Latin American exporters, 10 percent higher imported inputs, Asian exporters, 16 percent higher imported inputs, and African exporters, 19 percent higher imported inputs. The influence of foreign factors in this mechanism is also reflected in the correlation between exporting and foreign firm ownership. In columns 3 and 4 , we see that exporting firms have a much higher foreign firm participation. These links hold on average worldwide, and on average within each continent.

\subsection{Productivity}

We now turn to the correlation between productivity and exporting in the Enterprise Surveys. As we discussed in the literature review, firm productivity is one of the key better performance variables associated with exporting. The evidence in favor of this link is overwhelming, and it is not surprising that we find strong correlations in our data. We build three direct and indirect measures of firm productivity. First, we calculate labor productivity, which is value added per worker. Second, we measure TFP from OLS regressions of output on factor usage. Third, we use (log) sales as an indicator of productivity, as in Verhoogen (2008), Bustos (2011) and many others. We then regress these variables on the firm export status, as before. Results are in the last three columns of Table 5 .

Labor productivity is much higher for exporters (column 5). This holds for the worldwide average, for all regions, and for most countries. Productivity as measured by total factor productivity is also higher at exporters. In column 6, we estimate TFP using standard OLS 
regressions of outputs on factor use. The OLS-TFP premium is, on average, 10 percent. This premium is 8 percent in Europe, 13 percent in Latin America, 10 percent in Asia, and 7 percent in Africa. All these estimates are statistically significant. Since TFP estimated with OLS may be subject to well-known biases, we report in column 7 results based on TFP estimates using the econometric model of Ackerberg, Caves and Frazer (2015), which is a recent improvement over the corrections initially suggested by Olley and Pakes (1996). ACF-TFP offers larger productivity premium than OLS-TFP does. For instance, the world average premia is 19 percent (compared with 10 percent). This holds more generally for subset of countries: the premia are 24 percent in Africa, 18 percent in Latin America, and 20 in Asia. Only among European firms were we unable to estimate a statistically significant productivity premium. As a final robustness check, we regress log sales on exporting dummies (column 8). Sales are also much larger for exporting firm. On average, the sales premium is 1.86, but it can be as large as 2.06 in Latin America or 1.89 in Asia, to as low as 1.54 in Europe or 1.49 in Africa.

For our purposes, this correlation between exporting and productivity is useful for several reasons. Productivity is a clear indicator of firm performance, and consequently these correlations confirm the notion that exporters perform better, in general, than non-exporters. Also, much of the modern literature on trade with firm heterogeneity relies on productivity differences to explain firm decisions and the observation that exporters are more productive is consistent with this view. Finally, higher factor productivity and sales at exporting firms are consistent with the observation that exporters earn more profits than non-exporters. As such, they can afford to pay higher wages. This could happen because of an inherent complementarity with the other mechanisms explored above (skill use, imported inputs, technology, R\&D, investment, ownership) or because of additional mechanisms. That is, more productive firms can pay higher wages, ceteris paribus (that is, even conditional on skill utilization, imported inputs use, technology adoption and so on). This could occur under fair wages hypothesis, bargaining of profit sharing between firms and workers (Egger and Kreickemeier, 2009; Egger and Kreickemeier, 2010; Egger and Kreickemeier, 2012; Amiti and Davis, 2011). 


\section{Assessing the Export Wage Premium}

In this section, we perform two experiments to explain the estimated export wage premia. The first experiment is the estimation of a hybrid model of the wage premia. The second experiment is based on cross-country analysis.

\subsection{Explaining the Premia}

In the first experiment, we run a hybrid model where we estimate the export premium for wages conditional on the variables that capture the mechanisms. Our goals are to test whether the mechanisms make sense and, in addition, to explore how much of the export premium can be accounted for by them. Concretely, our expanded regression model is

$$
y_{i j}=\delta E_{i j}+\mathbf{m}_{i j}^{\prime} \gamma+\phi_{j}+u_{i j}
$$

where all variables are defined as above and $\mathbf{m}_{i j}$ are measures of the mechanisms, as in the discussion of the previous section. We include measures of skill utilization, technology, imported inputs, and productivity. We explore two specifications, "some controls" and "full controls." In the "some controls" specification, we include in $\mathbf{m}$ the ratio of skilled workers, the capital to labor ratio, the percentage of imports of intermediate inputs, and labor productivity. In the "full set of controls" specification, we keep the ratio of skilled workers, the capital to labor ratio, the percentage of imports of intermediate inputs, and labor productivity and we add iso certification, foreign ownership, and log sales. We add controls sequentially.

Results for the wage export premium are in Table 6. In both specifications, we observe that, as we add mechanisms $\mathbf{m}$, the wage premium declines. Controlling for skill composition alone (columns 2 and 6) does not affect the wage premium by much. Adding skill composition and technology together has sizeable effects on the wage premium. For instance, on average, the wage premium drops from 31 percent to between 21 and 18 percent in the "some control" and "full controls" specifications, respectively. If we further add imported inputs, the wage premium drops to between 17 and 11 percent, respectively. Finally, and most importantly, 
when we add measures of firm productivity, the wage premium disappears entirely. In this case, exporters and non-exporters would pay more or less the same wage, conditional on all the mechanisms.

\subsection{Cross-Country Correlations}

While we work with 61 countries, the evidence so far is based on cross-firm correlations within a country. Here, we exploit the cross-country correlations in the data as well. We correlate the wage premia reported in Table 2 with the premia corresponding to each of the four mechanisms estimated in Tables 3 and 4. The scatter plots and linear fits are reported in Figure 2.

In Panel A, we find a positive correlation between the wage export premia and the skill utilization premia. A similar positive correlation is found in Panel B (the sophistication of machine premia) and in Panel $\mathrm{C}$ (the productivity premia). These results suggests that countries with higher skill utilization export premia, higher machine sophistication export premia, and higher productivity export premia are countries with higher wage export premia. In the case of imported inputs, the correlation is much weaker (and it is actually slightly negative). Overall, thus, these results support the argument that the mechanisms outlined by the literature (skills, machine sophistication, input quality and productivity) are major determinants of the wage premia prevalent in the data.

\section{Conclusions}

The motivating fact behind this paper is the potential wage gains from exports in developing countries. The argument is that export markets bring about opportunities for firms and that successful exporting firms translate some of the benefits of exports to workers via employment and wage premia. Using comparable data for 61 developing and low-income countries, we document the prevalence of the export wage premia worldwide. With an extensive literature review, we identify four major drivers of the wage premia: exporting firms hire more skilled workers, utilize more sophisticated machines, buy higher quality material inputs, and are 
more productive than non-exporting firms. Our empirical analysis confirms the worldwide prevalence of these mechanisms and, furthermore, establishes a strong link to the estimated wage premia.

While the existence of a wage export premia is well-known, our results provide additional evidence for a wide range of lower income countries uncovered by most of the current literature. In turn, our study of the mechanisms sheds lights on how exporting firms behave and how export opportunities abroad can be beneficial for workers at home. This should matter for our understanding of the boosters that allow for, and of the constraints that prevent, the realization of the gains from trade in general and of exports in particular.

\section{References}

Acemoglu, D. and F. Zilibotti (2001). "Productivity Differences," Quarterly Journal of Economics 116(2), 563.606.

Ackerberg, D., K. Caves and G. Frazer (2015). "Identification Properties of Recent Production Function Estimators," Econometrica, 83(6), pp. 2411-2451.

Alvarez, R., and R. Lopez (2005). "Exporting and Performance: Evidence from Chilean Plants," Canadian Journal of Economics 38(4), pp. 1384-40.

Amiti, M. and D. D. R. Davis (2011). "Trade, Firms, and Wages: Theory and Evidence." Review of Economics Studies, vol 79, pp. 1-36.

Arnold, J., and K. Hussinger (2005). "Export Behavior and Firm Productivity in German Manufacturing: A Firm-Level Analysis," Review of World Economics 141(2), pp. 219-243.

Aw, B.Y. and G. Batra (1999). "Wages, Firm Size, and Wage Inequality: How Much Do Exports Matter?," in: Audretsch, D.B. and Thurik, A.R. (Eds.), Innovation, Industry Evolution, and Employment. Cambridge University Press, Cambridge, UK, pp. 13-56.

Aw, B.Y., M. Roberts and D.Y. Xu (2011). "R\&D Investment, Exporting, and Productivity Dynamics," American Economic Review, Vol. 101(4), pp. 1312-1344. 
Baldwin, R. and J. Harrigan (2011). "Zeros, Quality and Space: Trade Theory and Trade Evidence," American Economic Journal: Microeconomics, 3, pp. 60-88.

Bas, M. and V. Strauss-Kahn (2011). "Does Importing More Inputs Raise Exports? Firm Level Evidence from France," Review of World Economics, 1-35.

Bas. M. (2012). "Input-Trade Liberalization and Firm Export Decisions: Evidence from Argentina," Journal of Development Economics, Volume 97, Issue 2, pp. 481-493.

Bastos, P. and J. Silva (2010). "The Quality of a Firm's Exports: Where you Export to Matters," Journal of International Economics, vol. 82(2), pp. 99-111.

Bastos, P., J. Silva, and E. Verhoogen (2014). "Export Destinations and Input Prices: Evidence from Portugal," mimeo.

Baumgarten, D. (2013). "Exporters and the Rise in Wage Inequality: Evidence from German Linked Employer-Employee Data," Journal of International Economics, 90(1), pp. 201-217.

Bernard, A., and B. Jensen (1995). "Exporters, Jobs, and Wages in U.S. Manufacturing: 1976-1987.” In Brookings Papers on Economic Activity, Microeconomics: 1995, ed. G. L. Perry and W. C. Brainard, pp. 67-119. Washington, DC: Brookings Institution Press.

Bernard, A.B. and J.B. Jensen (1997). "Exporters, Skill Upgrading, and the Wage Gap," Journal of International Economics 42, pp. 3-31.

Bernard, A., and B. Jensen (1999). "Exceptional Exporter Performance: Cause, Effect, or Both?," Journal of International Economics 47 (1), pp. 1-25.

Bernard, A.B. and J.B. Jensen (2004). "Why Some Firms Export," Review of Economics and Statistics 86, pp. 561-569.

Bernard, A. and J. Wagner (1997). "Exports and Success in German Manufacturing," Weltwirtschaftliches Archiv, 133, pp. 134-157.

Bernard, A., B. Jensen, S. Redding, and P. Schott (2007). "Firms in International Trade," Journal of Economic Perspectives, Volume 21, Number 3, Summer 2007, pp. 105-130. 
Brambilla, I. D. Lederman, and G. Porto (2012). "Exports, Export Destinations and Skills," American Economic Review, Vol. 102, No. 7, pp. 3406-3438.

Bustos, P. (2011). "Trade Liberalization, Exports and Technology Upgrading: Evidence on the impact of MERCOSUR on Argentinean Firms," American Economic Review, vol. 101(1), pp. 304-340.

Bustos, P. (2014). "The Impact of Trade Liberalization on Skill Upgrading. Evidence from Argentina," mimeo CREI.

Caron, J., T. Fally, and J. Markusen (2014). "International Trade Puzzles: A Solution Linking Production and Preferences," forthcoming in the Quarterly Journal of Economics.

Clerides, S. K., S. Lach, and J. R. Tybout (1998). "Is Learning By Exporting Important? Micro-Dynamic Evidence From Colombia, Mexico, And Morocco," The Quarterly Journal of Economics, 113(3), pp. 903-947.

Crino, R. and P. Epifani (2012). "Productivity, Quality and Export Behavior," Economic Journal, 122(565), pp. 1206-1243

Delgado, Miguel A., J.C. Farinas and S. Ruano (2002). "Firm Productivity and Export Markets: a Non-parametric Approach," Journal of International Economics 57 (2), pp. $397-422$.

De Loecker, J. (2007). "Do Exports Generate Higher Productivity? Evidence from Slovenia," Journal of International Economics 73, pp. 69-98.

Egger, H. and U. Kreickemeier (2009). "Firm Heterogeneity and the Labor Market Effects of Trade Liberalization," International Economic Review, vol. 50, No. 1, pp.

Egger, H. and U. Kreickemeier (2010). "Worker-specific Effects of Globalisation," The World Economy, Wiley Blackwell, vol. 33(8), pp. 987-1005.

Egger, H. and U. Kreickemeier (2012). "Fairness, Trade, and Inequality," Journal of International Economics 86, pp. 184-196. 
Farinas, J.C. and A. Martin-Marcos (2007). "Exporting and Economic Performance: Firm-level Evidence of Spanish Manufacturing," The World Economy 30 (4), pp. 618-646.

Feng, L., Z. Li and D.L. Swenson (2012). "The Connection between Imported Intermediate Inputs and Exports: Evidence from Chinese Firms," NBER Working Papers 18260, National Bureau of Economic Research, Inc.

Feenstra, R. and J. Romalis (2012). "International Prices and Endogenous Quality," NBER Working Paper No. 18314.

Flam, H. and E. Helpman (1987). "Vertical Product Differentiation and North-South Trade," American Economic Review, 77 (5), pp. 810-822.

Frias, J.A, D.S. Kaplan, and E.A. Verhoogen (2009). "Exports and Wage Premia: Evidence from Mexican Employer-Employee Data," mimeo Columbia University.

Fryges, H. and J. Wagner (2008). "Exports and Productivity Growth: First Evidence from a Continuous Treatment Approach," Review of World Economics 144 (4), pp. 695-722.

Görg, H., L. Halpern and B. Muraközy (2010). "Why Do Within Firm-product Export Prices Differ Across Markets?," Kiel Working Paper No. 1596.

Greenaway, D. and Z. Yu (2004). "Firm-level Interactions Between Exporting and Productivity: Industry-specific Evidence," Review of World Economics / Weltwirtschaftliches Archiv 140, pp. 376-392.

Hahn, C.H. (2004). "Exporting and Performance of Plants: Evidence from Korean Manufacturing," National Bureau of Economic Research, NBER Working Paper Series No. 10208.

Hallak, J. C. (2006). "Product Quality and the Direction of Trade," Journal of International Economics, 62, pp. 238-265.

Hallak, J. C. (2010). "A Product-Quality View of the Linder Hypothesis," The Review of Economics and Statistics, vol. 92(3), pp. 453-466. 
Hallak, J.C. and J. Sivadasan (2013). "Product and Process Productivity: Implications for Quality Choice and Conditional Exporter Premia," Journal of International Economics, 91(1), pp. 53-67.

Hansson, P. and N.N. Lundin (2004). "Exports As an Indicator On or Promoter of Successful Swedish Manufacturing Firms in the 1990s," Review of World Economics / Weltwirtschaftliches Archiv 140, pp. 415-445.

Hummels, D. and P. Klenow (2005). "The Variety and Quality of a Nation's Exports," American Economic Review, 95 (3), pp. 704-723.

Isgut, A. (2001). "What's Different about Exporters? Evidence from Colombian Manufacturing," Journal of Development Studies 37 (5), pp. 57-82.

Johnson, R. (2012). "Trade and Prices with Heterogeneous Firms," Volume 86, Issue 1, pp. $43-56$.

Kandilov, I.T. (2009). "Do Exporters Pay Higher Wages? Plant-level Evidence from an Export Refund Policy in Chile," The World Bank Economic Review, Vol.23, NO. 2, pp. 269-294.

Kugler, M. and E. Verhoogen (2012). "Prices, Plant Size, and Product Quality," Review of Economic Studies, vol. 79 no. 1, pp. 307-339.

Lileeva, A. and D. Trefler (2010). "Improved Access to Foreign Markets Raises Plant-level Productivity...for Some Plants," The Quarterly Journal of Economics, 125(3), pp. 1051-1099.

Liu, J.T., M.W., Tsou and J.K. Hammitt (1999). "Export Activity and Productivity: Evidence from the Taiwan Electronics Industry," Weltwirtschaftliches Archiv / Review of World Economics 135, pp. 675-691.

Lopez, R.A. (2009). "Do Firms Increase Productivity in Order to Become Exporters?," Oxford Bulletin of Economics and Statistics, 71, 5. 
Manova, K. and Z. Zhang (2012). "Export Prices Across Firms and Destinations," Quaterly Journal of Economics, 127, pp. 379-436.

Marin.D. (1992). "Is the Export-led Growth Hypothesis Valid for Industrialized Countries?," Review of Economics and Statistics 74(4), pp. 678-88.

Matsuyama, K. (2007). "Beyond Icebergs: Towards A Theory of Biased Globalization," The Review of Economic Studies, 74, pp. 237-253.

Melitz, M. (2003). "The Impact of Trade on Intra-Industry Reallocations and Aggregate Industry Productivity," Econometrica 71, pp. 1695-1725.

Munch, J.R. and J.R. Skaksen (2008). "Human Capital and Wages in Exporting Firms," Journal of International Economics 75 (2), pp. 363-372.

Olley, S. and A. Pakes (1996). "The Dynamics of Productivity in the Telecommunications Equipment Industry," Econometrica, 64(6), pp. 1263-1297.

Park, A., D. Yang, X. Shi, and Y. Jiang (2010). "Exporting and Firm Performance: Chinese Exporters and the Asian Financial Crisis," The Review of Economics and Statistics, vol. 92, No. 4 , pp. 822-842.

Roberts, M.J. and J.R. Tybout (1997). "The Decision to Export in Colombia: An Empirical Model of Entry with Sunk Costs," American Economic Review, 87, pp. 545-564.

Schott, P. (2004). "Across-Product versus Within-Product Specialization in International Trade." Quarterly Journal of Economics, 119 (2), pp. 647-678.

Serti, F. and C. Tomassi (2008). "Self-Selection and Post-Entry Effects of Exports: Evidence from Italian Manufacturing Firms," Review of World Economics 144 (4): pp. 660-694.

Serti, F., C. Tomasi and A. Zanfei (2010). "Who Trades with Whom? Exploring the Links between Firms' International Activities, Skills, and Wages," Review of International Economics, 18(5), pp. 951-971. 
Söderbom, M. and F. Teal (2000). Skills, Investment, and Exports from Manufacturing Firms in Africa," Journal of Development Studies 37 (2), pp. 13-43.

Tsou, M.W., J.T. Liu and C.J. Huang (2006). "Export Activity, Firm Size and Wage Structure: Evidence from Taiwanese Manufacturing Firms," Asian Economic Journal, 20(4), pp. 333-354.

Van Biesebroeck, J. (2005). "Exporting Raises Productivity in Sub-Saharan African Manufacturing Plants," Journal of International Economics 67, pp. 373-391.

Verhoogen, E. (2008). "Trade, Quality Upgrading, and Wage Inequality in the Mexican Manufacturing Sector," Quarterly Journal of Economics, Vol 123, No. 2, pp. 489-530.

Wagner, J. (2002). "The Causal Effects of Exports on Firm Size and Labor Productivity: First Evidence from a Matching Approach," Economics Letters, 77(2), pp. 287-292.

Wagner, J. (2007). "Exports and Productivity: A survey of the Evidence from Firm-level Data," The World Economy, 30(1), pp. 60-82.

Yeaple, S. (2005). "A Simple Model of Firm Heterogeneity, International Trade and Wages," Journal of International Economics, 65, pp. 1-20.

Zhou, L. (2003). "Why Do Exporting Firms Pay Higher Wages?," Mimeo, Emory University, Atlanta. 
Table 1

Enterprise Survey

Coverage of Exporting Firms

\begin{tabular}{|c|c|c|c|c|}
\hline \multirow[t]{2}{*}{ Country } & \multirow[t]{2}{*}{ Year } & \multicolumn{3}{|c|}{ Exporting Firms } \\
\hline & & $\begin{array}{c}\text { sample } \\
\text { size }\end{array}$ & $\begin{array}{c}\text { share } \\
\text { exporters }\end{array}$ & $\begin{array}{l}\text { average } \\
\text { exports }\end{array}$ \\
\hline All countries & & & 0.34 & 0.53 \\
\hline Europe & & & 0.32 & 0.46 \\
\hline Bulgaria & 2007 & 497 & 0.45 & 0.57 \\
\hline Hungary & 2005 & 271 & 0.52 & 0.43 \\
\hline Macedonia & 2009 & 103 & 0.71 & 0.64 \\
\hline Moldova & 2009 & 107 & 0.4 & 0.67 \\
\hline Romania & 2009 & 107 & 0.33 & 0.73 \\
\hline Russia & 2012 & 858 & 0.17 & 0.19 \\
\hline Ukraine & 2008 & 368 & 0.29 & 0.5 \\
\hline Africa & & & 0.28 & 0.53 \\
\hline Angola & 2010 & 122 & 0.08 & 0.15 \\
\hline Botswana & 2006 & 112 & 0.21 & 0.37 \\
\hline Burundi & 2006 & 102 & 0.05 & 0.31 \\
\hline Congo D.Rep. & 2006 & 149 & 0.08 & 0.38 \\
\hline Egypt & 2004 & 954 & 0.24 & 0.37 \\
\hline Ethiopia & 2002 & 417 & 0.07 & 0.53 \\
\hline Ghana & 2007 & 292 & 0.22 & 0.31 \\
\hline Guinea & 2006 & 135 & 0.2 & 0.24 \\
\hline Ivory Coast & 2009 & 175 & 0.16 & 0.46 \\
\hline Kenya & 2007 & 396 & 0.43 & 0.32 \\
\hline Madagascar & 2005 & 210 & 0.34 & 0.83 \\
\hline Mali & 2007 & 234 & 0.12 & 0.38 \\
\hline Mauritius & 2009 & 161 & 0.42 & 0.57 \\
\hline Morocco & 2004 & 838 & 0.6 & 0.82 \\
\hline Mozambique & 2007 & 207 & 0.04 & 0.53 \\
\hline Namibia & 2006 & 104 & 0.33 & 0.39 \\
\hline Nigeria & 2007 & 948 & 0.03 & 0.28 \\
\hline Senegal & 2007 & 156 & 0.14 & 0.4 \\
\hline South Africa & 2003 & 554 & 0.61 & 0.23 \\
\hline Tanzania & 2006 & 272 & 0.15 & 0.25 \\
\hline Uganda & 2006 & 307 & 0.17 & 0.37 \\
\hline Zambia & 2007 & 237 & 0.1 & 0.15 \\
\hline Zimbabwe & 2011 & 317 & 0.16 & 0.27 \\
\hline
\end{tabular}


Table 1

Enterprise Survey

Coverage of Exporting Firms

(cont.)

\begin{tabular}{|c|c|c|c|c|}
\hline \multirow[t]{2}{*}{ Country } & \multirow[t]{2}{*}{ Year } & \multicolumn{3}{|c|}{ Exporting Firms } \\
\hline & & $\begin{array}{c}\text { sample } \\
\text { size }\end{array}$ & $\begin{array}{c}\text { share } \\
\text { exporters }\end{array}$ & $\begin{array}{l}\text { average } \\
\text { exports }\end{array}$ \\
\hline Latin America & & & 0.36 & 0.34 \\
\hline Argentina & 2010 & 671 & 0.55 & 0.25 \\
\hline Brazil & 2003 & 1575 & 0.31 & 0.25 \\
\hline Chile & 2004 & 688 & 0.43 & 0.38 \\
\hline Colombia & 2010 & 633 & 0.46 & 0.23 \\
\hline Costa Rica & 2005 & 296 & 0.31 & 0.39 \\
\hline Dominican Rep. & 2010 & 113 & 0.36 & 0.53 \\
\hline Ecuador & 2003 & 329 & 0.29 & 0.31 \\
\hline El Salvador & 2003 & 465 & 0.45 & 0.47 \\
\hline Guatemala & 2003 & 435 & 0.37 & 0.44 \\
\hline Honduras & 2003 & 428 & 0.35 & 0.6 \\
\hline Jamaica & 2010 & 109 & 0.28 & 0.34 \\
\hline Mexico & 2010 & 1062 & 0.34 & 0.28 \\
\hline Nicaragua & 2003 & 452 & 0.26 & 0.52 \\
\hline Panama & 2006 & 124 & 0.29 & 0.38 \\
\hline Paraguay & 2006 & 199 & 0.27 & 0.44 \\
\hline Peru & 2010 & 619 & 0.47 & 0.4 \\
\hline Uruguay & 2010 & 234 & 0.44 & 0.47 \\
\hline Asia & & & 0.36 & 0.69 \\
\hline Azerbaijan & 2009 & 109 & 0.18 & 0.35 \\
\hline Bangladesh & 2002 & 980 & 0.43 & 0.9 \\
\hline China & 2003 & 1309 & 0.25 & 0.5 \\
\hline India & 2000 & 855 & 0.29 & 0.87 \\
\hline Indonesia & 2003 & 667 & 0.43 & 0.7 \\
\hline Kazakhstan & 2005 & 244 & 0.14 & 0.28 \\
\hline Mongolia & 2009 & 130 & 0.25 & 0.55 \\
\hline Nepal & 2009 & 125 & 0.23 & 0.46 \\
\hline Pakistan & 2002 & 910 & 0.18 & 0.85 \\
\hline Philippines & 2003 & 665 & 0.39 & 0.78 \\
\hline Sri Lanka & 2004 & 404 & 0.7 & 0.88 \\
\hline Thailand & 2004 & 1385 & 0.62 & 0.62 \\
\hline Uzbekistan & 2008 & 120 & 0.28 & 0.37 \\
\hline Vietnam & 2005 & 1145 & 0.48 & 0.66 \\
\hline
\end{tabular}

Column (1): number of plants in the survey. Column (2): share of exporting firms. Column (3) average export participation in total sales, conditional on exporting. 
Table 2

Summary Statistics

\begin{tabular}{|c|c|c|c|c|c|c|c|c|}
\hline Country & $\begin{array}{l}\text { Skill } \\
\text { Ratio }\end{array}$ & $\begin{array}{c}\text { Capital } \\
\text { Labor }\end{array}$ & $\begin{array}{l}\text { ISO } \\
\text { Cert. }\end{array}$ & Importer & $\begin{array}{l}\text { Share } \\
\text { Imported } \\
\text { Inputs }\end{array}$ & $\begin{array}{c}\text { Foreign } \\
\text { Own. }\end{array}$ & $\begin{array}{c}\text { Majority } \\
\text { Foreign } \\
\text { Own. }\end{array}$ & TFP \\
\hline All countries & 1.64 & 8.59 & 0.22 & 0.51 & 0.27 & 0.12 & 0.09 & -0.06 \\
\hline Europe & 3.17 & 9.97 & 0.23 & 0.58 & 0.34 & 0.09 & 0.07 & 0.63 \\
\hline Bulgaria & 3.01 & 8.21 & 0.32 & 0.57 & 0.43 & 0.10 & 0.07 & 0.07 \\
\hline Hungary & 3.26 & & 0.27 & 0.66 & 0.34 & 0.17 & 0.14 & \\
\hline Macedonia & 2.70 & 12.42 & 0.39 & 0.79 & 0.59 & 0.17 & 0.13 & 1.63 \\
\hline Moldova & 2.81 & 9.99 & 0.19 & 0.64 & 0.46 & 0.21 & 0.16 & -2.31 \\
\hline Romania & 3.40 & 9.30 & 0.46 & 0.66 & 0.42 & 0.20 & 0.16 & 5.02 \\
\hline Russia & 2.84 & 10.33 & 0.17 & 0.60 & 0.29 & 0.04 & 0.02 & 0.31 \\
\hline Ukraine & 2.97 & 9.26 & 0.15 & 0.41 & 0.28 & 0.09 & 0.07 & 1.63 \\
\hline Africa & 1.67 & 8.84 & 0.15 & 0.52 & 0.31 & 0.15 & 0.11 & -0.30 \\
\hline Angola & 2.10 & 12.51 & 0.24 & 0.61 & 0.27 & 0.30 & 0.16 & -5.45 \\
\hline Botswana & 1.13 & 10.26 & 0.14 & 0.82 & 0.56 & 0.47 & 0.37 & 0.87 \\
\hline Burundi & 0.57 & 13.76 & 0.05 & 0.77 & 0.43 & 0.23 & 0.22 & -0.89 \\
\hline Congo D.Rep. & 1.08 & 13.47 & 0.07 & 0.58 & 0.30 & 0.31 & 0.27 & 0.07 \\
\hline Egypt & 2.05 & 3.48 & 0.09 & 0.32 & 0.17 & 0.04 & 0.03 & 0.05 \\
\hline Ethiopia & 1.13 & 2.79 & 0.02 & 0.66 & 0.45 & 0.04 & 0.03 & -0.81 \\
\hline Ghana & 2.23 & 15.22 & 0.07 & 0.46 & 0.22 & 0.07 & 0.05 & 0.07 \\
\hline Guinea & 1.83 & 13.86 & 0.05 & 0.65 & 0.43 & 0.11 & 0.10 & -0.43 \\
\hline Ivory Coast & 0.68 & & 0.05 & 0.31 & 0.23 & 0.27 & 0.23 & \\
\hline Kenya & 1.67 & 13.05 & 0.17 & 0.59 & 0.32 & 0.17 & 0.13 & -0.00 \\
\hline Madagascar & 0.66 & 8.60 & 0.08 & 0.58 & 0.49 & 0.39 & 0.32 & 0.65 \\
\hline Mali & 1.43 & 12.35 & 0.05 & 0.41 & 0.23 & 0.03 & 0.03 & 0.51 \\
\hline Mauritius & 1.00 & 11.60 & 0.13 & 0.55 & 0.49 & 0.11 & 0.09 & -5.97 \\
\hline Morocco & 2.55 & 3.52 & 0.08 & 0.80 & 0.60 & 0.19 & 0.13 & 0.56 \\
\hline Mozambique & 1.03 & 10.19 & 0.16 & 0.19 & 0.12 & 0.15 & 0.12 & -0.65 \\
\hline Namibia & 1.71 & 11.24 & 0.28 & 0.83 & 0.60 & 0.26 & 0.19 & 0.53 \\
\hline Nigeria & 1.36 & 11.60 & 0.09 & 0.28 & 0.10 & 0.01 & 0.01 & 0.09 \\
\hline Senegal & 1.38 & 13.88 & 0.08 & 0.42 & 0.24 & 0.08 & 0.07 & 0.19 \\
\hline South Africa & 2.08 & 5.06 & 0.42 & 0.69 & 0.23 & 0.19 & 0.15 & -1.68 \\
\hline Tanzania & 1.44 & 14.54 & 0.20 & 0.49 & 0.25 & 0.15 & 0.10 & -0.24 \\
\hline Uganda & 1.37 & 15.03 & 0.13 & 0.38 & 0.22 & 0.18 & 0.14 & 0.68 \\
\hline Zambia & 1.20 & 16.02 & 0.14 & 0.47 & 0.27 & 0.17 & 0.14 & 0.45 \\
\hline Zimbabwe & 0.94 & 10.00 & 0.32 & 0.58 & 0.28 & 0.21 & 0.03 & 0.27 \\
\hline
\end{tabular}

Variables: ratio of skilled to unskilled production workers (Column 1); log capital to labor ratio (Column 2); Indicator variable for ISO-certified products (Column 3); Indicator variable for imported inputs (Column 4); Percentage of inputs that are imported (Column 5); Indicator variable for some percentage of foreign ownership (Column 6); Indicator variable for more than 50 percent of foreign ownership (Column 7); Total factor productivity (Column 8). 
Table 2

Summary Statistics

(cont.)

\begin{tabular}{|c|c|c|c|c|c|c|c|c|}
\hline Country & $\begin{array}{l}\text { Skill } \\
\text { Ratio }\end{array}$ & $\begin{array}{l}\text { Capital } \\
\text { Labor }\end{array}$ & $\begin{array}{l}\text { ISO } \\
\text { Cert. }\end{array}$ & Importer & $\begin{array}{c}\text { Share } \\
\text { Imported } \\
\text { Inputs }\end{array}$ & $\begin{array}{c}\text { Foreign } \\
\text { Own. }\end{array}$ & $\begin{array}{c}\text { Majority } \\
\text { Foreign } \\
\text { Own. }\end{array}$ & TFP \\
\hline Latin America & 1.26 & 8.84 & 0.20 & 0.64 & 0.30 & 0.10 & 0.08 & -0.01 \\
\hline Argentina & 1.47 & 10.08 & 0.39 & 0.82 & 0.30 & 0.15 & 0.14 & 0.32 \\
\hline Brazil & 1.56 & 2.88 & 0.19 & 0.44 & 0.11 & 0.05 & 0.04 & 0.07 \\
\hline Chile & 1.34 & 9.53 & 0.31 & 0.53 & 0.20 & 0.16 & 0.10 & 0.13 \\
\hline Colombia & 1.03 & 16.09 & 0.34 & 0.74 & 0.33 & 0.11 & 0.07 & 0.26 \\
\hline Costa Rica & 1.00 & 1.74 & 0.09 & 0.48 & 0.30 & 0.08 & 0.07 & -1.48 \\
\hline Dominican Rep. & 1.27 & 12.06 & 0.24 & 0.75 & 0.50 & 0.21 & 0.19 & 0.99 \\
\hline Ecuador & 1.78 & 1.83 & 0.16 & 0.71 & 0.40 & 0.12 & 0.08 & -0.90 \\
\hline El Salvador & 0.94 & 3.39 & 0.05 & 0.55 & 0.35 & 0.09 & 0.06 & 0.59 \\
\hline Guatemala & 0.43 & 3.55 & 0.03 & 0.54 & 0.31 & 0.09 & 0.08 & -0.58 \\
\hline Honduras & 0.60 & 3.62 & 0.05 & 0.47 & 0.30 & 0.12 & 0.09 & -0.97 \\
\hline Jamaica & 1.59 & 13.46 & 0.20 & 0.76 & 0.42 & 0.16 & 0.06 & -0.13 \\
\hline Mexico & 1.32 & 11.60 & 0.24 & 0.63 & 0.23 & 0.10 & 0.07 & -0.34 \\
\hline Nicaragua & 0.78 & 3.66 & 0.03 & 0.56 & 0.34 & 0.10 & 0.08 & -0.71 \\
\hline Panama & 0.89 & 8.99 & 0.16 & 0.77 & 0.46 & 0.15 & 0.13 & 0.11 \\
\hline Paraguay & 0.72 & 17.09 & 0.09 & 0.83 & 0.47 & 0.13 & 0.08 & 5.31 \\
\hline Peru & 1.22 & 9.95 & 0.27 & 0.84 & 0.39 & 0.13 & 0.08 & -0.00 \\
\hline Uruguay & 1.28 & 11.54 & 0.21 & 0.92 & 0.54 & 0.10 & 0.08 & -1.75 \\
\hline Asia & 1.65 & 8.08 & 0.29 & 0.38 & 0.22 & 0.13 & 0.08 & -0.04 \\
\hline Azerbaijan & 6.11 & 8.08 & 0.38 & 0.42 & 0.21 & 0.21 & 0.16 & 1.55 \\
\hline Bangladesh & 3.48 & 4.50 & & 0.61 & 0.48 & 0.03 & 0.02 & -0.09 \\
\hline China & 0.18 & 4.59 & 0.49 & 0.21 & 0.06 & 0.18 & 0.10 & \\
\hline India & 1.74 & 4.93 & & 0.16 & 0.07 & 0.04 & 0.01 & 0.10 \\
\hline Indonesia & 1.80 & 8.93 & 0.22 & & & 0.17 & 0.15 & -0.79 \\
\hline Kazakhstan & 3.50 & & 0.09 & 0.36 & 0.23 & 0.06 & 0.04 & \\
\hline Mongolia & 2.02 & 14.63 & 0.20 & 0.66 & 0.40 & 0.12 & 0.08 & 0.89 \\
\hline Nepal & 1.00 & 11.76 & 0.16 & 0.66 & 0.44 & 0.03 & 0.02 & -2.94 \\
\hline Pakistan & 2.93 & 12.97 & 0.17 & 0.16 & 0.09 & 0.01 & 0.01 & -1.89 \\
\hline Philippines & 2.27 & 4.29 & 0.16 & 0.52 & 0.35 & 0.24 & 0.17 & 0.97 \\
\hline Sri Lanka & 3.37 & 5.28 & & 0.53 & 0.40 & 0.20 & 0.13 & -1.10 \\
\hline Uzbekistan & 2.63 & 14.41 & 0.20 & 0.36 & 0.15 & 0.28 & 0.11 & -1.49 \\
\hline Vietnam & 4.67 & 10.55 & 0.38 & 0.56 & 0.36 & 0.12 & 0.10 & 0.08 \\
\hline
\end{tabular}

Variables: ratio of skilled to unskilled production workers (Column 1); log capital to labor ratio (Column 2); Indicator variable for ISO-certified products (Column 3); Indicator variable for imported inputs (Column 4); Percentage of inputs that are imported (Column 5); Indicator variable for some percentage of foreign ownership (Column 6); Indicator variable for more than 50 percent of foreign ownership (Column 7); Total factor productivity (Column 8). 
Table 3

Wage Export Premia Across Developing Countries

\begin{tabular}{|c|c|c|c|c|}
\hline \multirow[t]{2}{*}{ Country } & \multirow{2}{*}{$\begin{array}{c}\text { All } \\
\text { Sectors }\end{array}$} & \multirow{2}{*}{$\begin{array}{c}\text { Selected } \\
\text { Industries }\end{array}$} & \multicolumn{2}{|c|}{ With Controls } \\
\hline & & & All & Selected \\
\hline All countries & $0.31^{* * *}$ & $0.28^{* * *}$ & $0.25^{* * *}$ & $0.23^{* * *}$ \\
\hline Europe & $0.20 * * *$ & $0.21^{* * *}$ & $0.17^{* * *}$ & $0.18^{* * *}$ \\
\hline Bulgaria & $0.23^{* * *}$ & $0.18^{* * *}$ & $0.18^{* * *}$ & $0.15^{* * *}$ \\
\hline Hungary & $0.09^{* *}$ & $0.10^{* * *}$ & 0.05 & $0.07^{* *}$ \\
\hline Macedonia & $0.46^{* *}$ & $0.61^{*}$ & 0.4 & 0.56 \\
\hline Moldova & $0.67^{* * *}$ & $0.85^{* * *}$ & $0.64 * * *$ & $0.74^{* *}$ \\
\hline Romania & $0.15^{*}$ & $0.07^{* *}$ & 0.11 & $0.05^{* *}$ \\
\hline Romania & 0.12 & 0.1 & 0.22 & 0.14 \\
\hline Russia & $0.26^{* *}$ & $0.40^{* * *}$ & $0.23^{* * *}$ & $0.34^{* * *}$ \\
\hline Ukraine & $0.21^{* *}$ & $0.20^{*}$ & $0.20^{*}$ & 0.21 \\
\hline Africa & $0.22^{* * *}$ & $0.19^{* * *}$ & $0.18^{* * *}$ & $0.15^{* * *}$ \\
\hline Angola & 0.16 & 0.26 & $0.54^{* *}$ & $0.63^{*}$ \\
\hline Botswana & 0.1 & -0.06 & 0.05 & -0.1 \\
\hline Burundi & $0.41^{*}$ & $0.83^{* * *}$ & 0.36 & $0.85^{* * *}$ \\
\hline Congo D.Rep. & 0.21 & $0.70 * * *$ & 0.14 & $0.68^{* * *}$ \\
\hline Egypt & $0.19^{* *}$ & 0.1 & $0.16^{* *}$ & 0.08 \\
\hline Ethiopia & $0.63^{*}$ & $1.10^{* *}$ & $0.62^{*}$ & $1.06^{* *}$ \\
\hline Ghana & 0.06 & -0.03 & 0.03 & -0.03 \\
\hline Guinea & 0.14 & -0.05 & 0.07 & -0.17 \\
\hline Ivory Coast & $0.77^{* *}$ & $1.03^{* * *}$ & $0.64^{*}$ & $0.76^{* * *}$ \\
\hline Kenya & 0.07 & 0.04 & 0.07 & 0.05 \\
\hline Madagascar & 0.2 & 0.21 & 0.13 & 0.12 \\
\hline Mali & $0.57^{* * *}$ & $0.57^{* * *}$ & $0.55^{* * *}$ & $0.55^{* * *}$ \\
\hline Mauritius & 0.37 & 0.1 & 0.24 & -0.01 \\
\hline Morocco & 0.1 & -0.01 & 0.05 & -0.04 \\
\hline Mozambique & $0.55^{* * *}$ & 0.35 & $0.44^{* * *}$ & 0.34 \\
\hline Namibia & $0.35^{*}$ & $-0.26^{* * *}$ & $0.36^{* *}$ & $-0.25^{*}$ \\
\hline Nigeria & $0.40 * * *$ & $0.34^{* * *}$ & $0.38 * * *$ & $0.30^{* * *}$ \\
\hline Senegal & 0.42 & 0.49 & 0.39 & 0.45 \\
\hline South Africa & $0.32^{* * *}$ & $0.29 * * *$ & $0.28 * * *$ & $0.23^{* * *}$ \\
\hline Tanzania & -0.08 & 0.21 & -0.15 & 0.16 \\
\hline Uganda & $0.35^{* * *}$ & $0.39 * * *$ & $0.23^{* * *}$ & $0.24^{* * *}$ \\
\hline Zambia & $0.47^{* * *}$ & $0.47^{* * *}$ & $0.45^{* *}$ & $0.45^{* *}$ \\
\hline Zimbabwe & 0.07 & -0.05 & 0.02 & -0.13 \\
\hline
\end{tabular}

Column (1): Wage Premium (percentage difference in wages of exporters and non-exporters, controlling for country-industry-year interaction effects) for all firms. Column (2): Wage premium for plants in Textiles, Garments, Food, Beverages, and Metals and Machinery. Columns (3) and (4): same as (1) and (2), but controlling for foreign ownership. 
Table 3

Wage Export Premia Across Developing Countries (cont.)

\begin{tabular}{|c|c|c|c|c|}
\hline \multirow[t]{2}{*}{ Country } & \multirow{2}{*}{$\begin{array}{c}\text { All } \\
\text { Sectors }\end{array}$} & \multirow{2}{*}{$\begin{array}{c}\text { Selected } \\
\text { Industries }\end{array}$} & \multicolumn{2}{|c|}{ With Controls } \\
\hline & & & All & Selected \\
\hline Latin America & $0.38^{* * *}$ & $0.34^{* * *}$ & $0.33^{* * *}$ & $0.29^{* * *}$ \\
\hline Argentina & $0.31^{* * *}$ & $0.35^{* * *}$ & $0.18^{* *}$ & $0.23^{* * *}$ \\
\hline Brazil & $0.51^{* * *}$ & $0.50 * * *$ & $0.44^{* * *}$ & $0.43^{* * *}$ \\
\hline Chile & 0.26 & -0.07 & 0.23 & -0.06 \\
\hline Colombia & $0.42^{* * *}$ & $0.36^{* * *}$ & $0.32^{* * *}$ & $0.31^{* * *}$ \\
\hline Costa Rica & $0.45^{* * *}$ & 0.51 & $0.41^{* * *}$ & 0.54 \\
\hline Dominican Rep. & 0.17 & 0.21 & 0.1 & 0.18 \\
\hline Ecuador & 0.21 & 0.14 & 0.17 & 0.03 \\
\hline El Salvador & $0.39 * * *$ & $0.39 * * *$ & $0.36^{* * *}$ & $0.35 * * *$ \\
\hline Guatemala & 0.19 & 0.11 & $0.21^{* *}$ & 0.15 \\
\hline Honduras & $0.41^{* * *}$ & $0.47^{* * *}$ & $0.35^{* * *}$ & $0.36^{* * *}$ \\
\hline Jamaica & $0.32^{* * *}$ & 0.26 & $0.27 * * *$ & 0.25 \\
\hline Mexico & $0.44^{* * *}$ & $0.52^{* * *}$ & $0.37^{* * *}$ & $0.46^{* * *}$ \\
\hline Nicaragua & 0.1 & 0.03 & 0.02 & -0.05 \\
\hline Panama & 0.24 & -0.02 & 0.25 & -0.04 \\
\hline Paraguay & 0.06 & 0.56 & 0.07 & $0.64^{* * *}$ \\
\hline Peru & $0.52^{* * *}$ & $0.61^{* * *}$ & $0.41^{* * *}$ & $0.51^{* * *}$ \\
\hline Uruguay & $0.51^{* * *}$ & $0.38^{* * *}$ & $0.47^{* * *}$ & $0.37 * * *$ \\
\hline Asia & $0.30^{* * *}$ & $0.29 * * *$ & $0.21^{* * *}$ & $0.22^{* * *}$ \\
\hline Azerbaijan & 0.09 & 0.12 & $0.07^{* *}$ & 0.04 \\
\hline Bangladesh & 0.1 & 0.05 & 0.09 & 0.04 \\
\hline China & $0.42^{* * *}$ & $0.43^{* * *}$ & $0.31^{* * *}$ & $0.40^{* * *}$ \\
\hline India & 0.05 & -0.02 & 0.02 & -0.03 \\
\hline Indonesia & $0.33^{* *}$ & $0.49^{* * *}$ & 0.23 & $0.39^{* *}$ \\
\hline Kazakhstan & $0.19^{* *}$ & $0.17^{* *}$ & $0.18^{* *}$ & 0.14 \\
\hline Mongolia & $0.44^{*}$ & $0.75^{* * *}$ & 0.36 & $0.55^{* *}$ \\
\hline Nepal & 0.09 & 0.02 & 0.02 & 0.02 \\
\hline Pakistan & $0.28^{*}$ & 0.08 & $0.27^{*}$ & 0.09 \\
\hline Philippines & $0.62^{* * *}$ & $0.69^{* * *}$ & $0.45^{* * *}$ & $0.51^{* * *}$ \\
\hline Sri Lanka & $0.36^{* *}$ & $0.34^{*}$ & $0.27^{*}$ & 0.24 \\
\hline Thailand & $0.29^{* * *}$ & $0.26^{* * *}$ & $0.20 * * *$ & $0.16^{* * *}$ \\
\hline Uzbekistan & 0.19 & 0.2 & 0.15 & 0.25 \\
\hline Vietnam & 0.08 & 0.06 & -0.01 & -0.04 \\
\hline
\end{tabular}

Column (1): Wage Premium (percentage difference in wages of exporters and non-exporters, controlling for country-industry-year interaction effects) for all firms. Column (2): Wage premium for plants in Textiles, Garments, Food, Beverages, and Metals and Machinery. Columns (3) and (4): same as (1) and (2), but controlling for foreign ownership. 
Table 4

Skill Utilization and Machine Sophistication

Exporting Firms' Premium

\begin{tabular}{|c|c|c|c|c|c|c|c|c|}
\hline \multirow{2}{*}{ Country } & \multicolumn{4}{|c|}{ Skill Utilization } & \multicolumn{4}{|c|}{ Machine Sophistication } \\
\hline & $\begin{array}{c}\text { ratio } \\
\text { skilled } \\
\text { workers }\end{array}$ & $\begin{array}{l}\text { share } \\
\text { high } \\
\text { school }\end{array}$ & $\begin{array}{c}\text { manager } \\
\text { with } \\
\text { college }\end{array}$ & $\begin{array}{c}\text { manager } \\
\text { with } \\
\text { pos-grad }\end{array}$ & $\begin{array}{c}\text { capital } \\
\text { labor } \\
\text { ratio }\end{array}$ & $\begin{array}{c}\text { ISO } \\
\text { Certf. }\end{array}$ & $\begin{array}{l}\text { New } \\
\text { Tech. }\end{array}$ & $\begin{array}{c}\text { R\&D } \\
\text { Spenging }\end{array}$ \\
\hline All countries & $0.91^{* * *}$ & $0.04^{* * *}$ & $0.17^{* * *}$ & $0.12^{* * *}$ & $0.44^{* * *}$ & $0.24^{* * *}$ & $0.11^{* * *}$ & $0.05^{* * *}$ \\
\hline Europe & $1.99 * * *$ & $0.05^{* * *}$ & - & - & $0.45^{* * *}$ & $0.21^{* * *}$ & 0.04 & $0.16^{* * *}$ \\
\hline Bulgaria & 0.95 & - & - & - & 0.26 & $0.17^{* * *}$ & - & - \\
\hline Hungary & 1.08 & $0.05^{* * *}$ & - & - & & $0.13^{* * *}$ & 0.04 & $0.16^{* * *}$ \\
\hline Macedonia & $1.72^{* * *}$ & - & - & - & $1.21^{* * *}$ & $0.37^{* *}$ & - & - \\
\hline Moldova & $1.29 *$ & - & - & - & $0.95^{* * *}$ & $0.37 * * *$ & - & - \\
\hline Romania & $4.37^{*}$ & - & - & - & 0.54 & 0.09 & - & - \\
\hline Russia & $2.71^{* * *}$ & - & - & - & $0.39^{* * *}$ & $0.22^{* * *}$ & - & - \\
\hline Ukraine & $3.20^{* * *}$ & - & - & - & $0.94^{* * *}$ & $0.26^{* * *}$ & - & - \\
\hline Africa & $0.74^{* * *}$ & 0.01 & $0.19^{* * *}$ & $0.13^{* * *}$ & $0.17^{* * *}$ & $0.20 * * *$ & $0.15^{* * *}$ & $0.04^{* * *}$ \\
\hline Angola & 1.76 & -0.01 & - & - & 0.25 & $0.50 * * *$ & - & - \\
\hline Botswana & $1.63^{* * *}$ & - & - & - & 0.34 & 0.1 & - & - \\
\hline Burundi & 1.56 & - & - & - & 0.68 & 0.41 & - & - \\
\hline Congo D.Rep. & -0.01 & - & - & - & 0.05 & $0.20^{* *}$ & - & - \\
\hline Egypt & 0.67 & $0.04^{* * *}$ & $0.08^{* * *}$ & $0.03^{* * *}$ & 0.28 & $0.26^{* * *}$ & $0.17^{* * *}$ & $0.12^{* * *}$ \\
\hline Ethiopia & -0.05 & - & $0.22^{* * *}$ & - & $0.88^{* *}$ & $-0.03^{*}$ & - & $0.14^{*}$ \\
\hline Ghana & $2.46^{* * *}$ & - & - & - & 0.09 & 0.11 & - & - \\
\hline Guinea & -0.17 & - & - & - & 0.21 & $0.16^{* *}$ & - & - \\
\hline Ivory Coast & 0.75 & - & - & & & 0.16 & - & - \\
\hline Kenya & -0.06 & - & - & - & $0.26 * * *$ & $0.24^{* * *}$ & - & - \\
\hline Madagascar & -0.05 & -0.06 & 0.37 & 0.14 & -0.86 & $0.16^{*}$ & $0.27^{* *}$ & - \\
\hline Mali & $-0.77^{* * *}$ & - & - & - & $0.59^{* * *}$ & $0.31^{* * *}$ & - & - \\
\hline Mauritius & 0.25 & - & - & - & -0.56 & $0.18^{* *}$ & - & - \\
\hline Morocco & $1.25^{* *}$ & 0.01 & $0.24^{* * *}$ & $0.17^{* * *}$ & 0.07 & $0.11^{* *}$ & $0.19^{* * *}$ & $0.04^{* * *}$ \\
\hline Mozambique & $-0.59 * * *$ & - & - & - & 0.08 & $0.76^{* * *}$ & - & - \\
\hline Namibia & 0.61 & - & - & - & $0.23^{*}$ & 0.3 & - & - \\
\hline Nigeria & $1.01^{*}$ & - & - & - & $0.80^{* * *}$ & $0.31^{* *}$ & - & - \\
\hline Senegal & -0.15 & - & - & - & $-0.23^{* *}$ & 0.19 & - & - \\
\hline South Africa & $1.28^{* *}$ & 0.02 & $0.24^{* * *}$ & $0.19^{* * *}$ & 0.29 & $0.22^{* * *}$ & 0.04 & $0.16^{* * *}$ \\
\hline Tanzania & 0.53 & - & - & - & $1.01^{* * *}$ & 0.04 & - & - \\
\hline Uganda & 0.21 & - & - & - & $0.70^{* * *}$ & $0.26^{* * *}$ & - & - \\
\hline Zambia & $1.61^{* * *}$ & - & - & - & 0.27 & $0.35^{* * *}$ & - & - \\
\hline Zimbabwe & -0.08 & -0.03 & - & - & $-0.39^{*}$ & $0.27^{* * *}$ & - & - \\
\hline
\end{tabular}

Export premium controlling for country-industry-year interaction effects. Variables: ratio of skilled to unskilled production workers (Column 1); Share of workers with high school education or more (Column 2); Manager has a college degree (Column 3); Manager has post-graduate education (Column 4); log capital to labor ratio (Column 5); Indicator variable for ISO-certified products (Column $6)$; Indicator variable for whether new production technology 3 introduced in the past 3 years (Column 7 ); Indicator variable for positive R\&D spending (Column 8). 
Table 4

Skill Utilization and Machine Sophistication

Exporting Firms' Premium

(cont.)

\begin{tabular}{|c|c|c|c|c|c|c|c|c|}
\hline \multirow[t]{2}{*}{ Country } & \multicolumn{4}{|c|}{ Skill Utilization } & \multicolumn{4}{|c|}{ Machine Sophistication } \\
\hline & $\begin{array}{c}\text { ratio } \\
\text { skilled } \\
\text { workers }\end{array}$ & $\begin{array}{l}\text { share } \\
\text { high } \\
\text { school }\end{array}$ & $\begin{array}{c}\text { manager } \\
\text { with } \\
\text { college }\end{array}$ & $\begin{array}{c}\text { manager } \\
\text { with } \\
\text { pos-grad }\end{array}$ & $\begin{array}{c}\text { capital } \\
\text { labor } \\
\text { ratio }\end{array}$ & $\begin{array}{l}\text { ISO } \\
\text { Certf. }\end{array}$ & $\begin{array}{l}\text { New } \\
\text { Tech. }\end{array}$ & $\begin{array}{c}\text { R\&D } \\
\text { Spenging }\end{array}$ \\
\hline Latin America & $0.65^{* * *}$ & $0.05^{* * *}$ & $0.25^{* * *}$ & $0.18^{* * *}$ & $0.52^{* * *}$ & $0.26^{* * *}$ & $0.09 * * *$ & $0.05^{* * *}$ \\
\hline Argentina & $0.63^{* * *}$ & $0.10^{* * *}$ & - & - & $0.66^{* * *}$ & $0.36^{* * *}$ & - & - \\
\hline Brazil & $0.72^{* * *}$ & $0.04 * * *$ & $0.22^{* * *}$ & $0.19^{* * *}$ & $0.61^{* * *}$ & $0.22^{* * *}$ & 0.04 & $0.21^{* * *}$ \\
\hline Chile & $0.60^{*}$ & 0.04 & $0.20 * * *$ & $0.17^{* * *}$ & $0.73^{* * *}$ & $0.35^{* * *}$ & $0.14^{* * *}$ & $0.13^{* * *}$ \\
\hline Brazil & $1.34^{* * *}$ & - & - & - & $0.67 * * *$ & $0.24^{* * *}$ & - & - \\
\hline Colombia & $0.43^{* * *}$ & $0.04^{* * *}$ & - & - & $0.42^{* * *}$ & $0.41^{* * *}$ & - & - \\
\hline Costa Rica & $0.89^{*}$ & $0.08^{* * *}$ & $0.43^{* * *}$ & $0.30 * * *$ & $0.53^{* * *}$ & $0.26^{* * *}$ & $0.14^{* *}$ & $0.10^{* *}$ \\
\hline Dominican Rep & 0.52 & $-0.20^{* * *}$ & - & - & 0.14 & $0.22^{* *}$ & - & - \\
\hline Ecuador & $2.41^{*}$ & $-0.05^{* * *}$ & $0.08^{*}$ & $0.15^{* * *}$ & $0.77^{* * *}$ & $0.24^{* * *}$ & $0.11^{*}$ & $0.12^{* * *}$ \\
\hline El Salvador & $0.51^{* * *}$ & $0.21^{* * *}$ & $0.35^{* * *}$ & $0.20 * * *$ & $0.62^{* * *}$ & $0.09 * * *$ & $0.17^{* *}$ & $0.12^{* * *}$ \\
\hline Guatemala & 0.11 & $-0.10^{* * *}$ & $0.29 * * *$ & $0.16^{* * *}$ & 0.08 & 0.01 & $0.18^{* * *}$ & $0.15^{*}$ \\
\hline Honduras & -0.04 & $0.15^{*}$ & $0.37^{* * *}$ & $0.15^{* * *}$ & $0.30 * *$ & $0.06^{* * *}$ & 0.03 & $0.14^{* * *}$ \\
\hline Jamaica & -0.11 & 0.03 & - & - & $0.59^{*}$ & $0.13^{* *}$ & - & - \\
\hline Mexico & $0.39^{* * *}$ & $0.09 * * *$ & - & - & $0.36^{* * *}$ & $0.34^{* * *}$ & - & - \\
\hline Nicaragua & 0.02 & 0.08 & $0.19^{* * *}$ & $0.14^{* * *}$ & 0.11 & 0.02 & -0.04 & $0.08^{*}$ \\
\hline Panama & 0.93 & - & - & - & 0.07 & -0.01 & - & - \\
\hline Paraguay & 0.02 & - & - & - & $0.74^{* * *}$ & $0.14^{* *}$ & - & - \\
\hline Peru & 0.22 & $0.02^{*}$ & - & & $0.60 * * *$ & $0.31^{* * *}$ & - & - \\
\hline Uruguay & 0.52 & 0.08 & - & - & $1.11^{* * *}$ & $0.27^{* * *}$ & - & - \\
\hline Asia & $1.04^{* * *}$ & $0.05^{* * *}$ & $0.13^{* * *}$ & $0.08^{* * *}$ & $0.50^{* * *}$ & $0.27^{* * *}$ & $0.11^{* * *}$ & $0.07^{* * *}$ \\
\hline Azerbaijan & 1.98 & - & - & - & $-1.03^{* *}$ & $0.28^{* * *}$ & - & - \\
\hline Bangladesh & 2.62 & - & 0.06 & 0.01 & 0.08 & - & - & 0.04 \\
\hline China & $0.02 *$ & - & $0.11^{* * *}$ & $0.09^{* * *}$ & $0.61^{* * *}$ & $0.18^{* *}$ & 0.08 & $0.18^{* *}$ \\
\hline India & $1.38^{* *}$ & - & $0.08^{*}$ & - & 0.11 & - & - & - \\
\hline Indonesia & 1.11 & $0.09^{* *}$ & $0.28^{* * *}$ & $0.09 * * *$ & $0.76^{* * *}$ & $0.19^{* * *}$ & $0.08^{* *}$ & - \\
\hline Kazakhstan & $3.47^{* * *}$ & 0.06 & - & - & - & $0.07^{* * *}$ & 0.02 & $0.04^{*}$ \\
\hline Mongolia & 0.74 & - & - & - & $0.95^{* *}$ & $0.45^{* * *}$ & - & - \\
\hline Nepal & 0.6 & - & - & - & $0.88^{* *}$ & 0.08 & - & - \\
\hline Pakistan & $1.72^{* *}$ & $0.05^{*}$ & $0.27^{* * *}$ & $0.25^{* * *}$ & -0.14 & $0.45^{* * *}$ & - & -0.0018 \\
\hline Philippines & $2.25^{* *}$ & - & $0.16^{* * *}$ & $0.12^{* * *}$ & $0.66^{* * *}$ & $0.21^{*}$ & $0.16^{* * *}$ & $0.15^{* * *}$ \\
\hline Sri Lanka & 2.57 & $0.04^{*}$ & 0.06 & 0.01 & 0.05 & - & - & 0.02 \\
\hline Thailand & -0.07 & $0.04^{* *}$ & $0.16^{* * *}$ & - & $1.22^{* * *}$ & $0.28^{* * *}$ & $0.14^{* * *}$ & $0.14^{* * *}$ \\
\hline Uzbekistan & 1.3 & - & - & - & -0.31 & $0.44^{* * *}$ & - & - \\
\hline Vietnam & $2.08^{* * *}$ & 0.0027 & $0.14^{* * *}$ & 0.02 & 0.04 & $0.25^{* * *}$ & $0.11^{* *}$ & $0.07^{* * *}$ \\
\hline
\end{tabular}

Export premium controlling for country-industry-year interaction effects. Variables: ratio of skilled to unskilled production workers (Column 1); Share of workers with high school education or more (Column 2); Manager has a college degree (Column 3); Manager has post-graduate education (Column 4); log capital to labor ratjo (Column 5); Indicator variable for ISO-certified products (Column 6 ); Indicator variable for whether new production technology was introduced in the past 3 years (Column 7); Indicator variable for positive R\&D spending (Column 8). 
Table 5

Imported Inputs and Productivity

Exporting Firms' Premium

\begin{tabular}{|c|c|c|c|c|c|c|c|c|}
\hline \multirow[t]{3}{*}{ Country } & \multicolumn{4}{|c|}{ Imported Inputs } & \multicolumn{3}{|c|}{ Productivity } & \multirow{3}{*}{$\begin{array}{c}\log \\
\text { sales }\end{array}$} \\
\hline & \multirow[t]{2}{*}{ importer } & \multirow{2}{*}{$\begin{array}{c}\text { share } \\
\text { imported } \\
\text { inputs }\end{array}$} & \multirow[t]{2}{*}{ foreign } & \multirow{2}{*}{$\begin{array}{c}\text { majority } \\
\text { foreign }\end{array}$} & \multirow{2}{*}{$\begin{array}{c}\text { output } \\
\text { per } \\
\text { worker }\end{array}$} & \multicolumn{2}{|c|}{ TFP } & \\
\hline & & & & & & OLS & $\mathrm{ACF}$ & \\
\hline All countries & $0.27^{* * *}$ & $0.14^{* * *}$ & $0.17^{* * *}$ & $0.13^{* * *}$ & $0.53^{* * *}$ & $0.10^{* * *}$ & $0.19^{* * *}$ & $1.86^{* * *}$ \\
\hline Europe & $0.20^{* * *}$ & $0.14^{* * *}$ & $0.15^{* * *}$ & $0.11^{* * *}$ & $0.30^{* * *}$ & $0.08^{* * *}$ & -0.09 & $1.54^{* * *}$ \\
\hline Bulgaria & $0.18^{* * *}$ & $0.17^{* *}$ & $0.15^{* * *}$ & $0.11^{* * *}$ & $0.31^{* * *}$ & $0.10^{* * *}$ & 0.13 & $1.18^{* * *}$ \\
\hline Hungary & $0.35^{* * *}$ & $0.23^{* * *}$ & $0.25^{* * *}$ & $0.22^{* * *}$ & $0.18^{* * *}$ & - & - & $1.58^{* * *}$ \\
\hline Macedonia & $0.31^{* * *}$ & 0.15 & $0.20^{* *}$ & $0.16^{* *}$ & $0.53^{* *}$ & 0.15 & -0.57 & $2.09^{* * *}$ \\
\hline Moldova & -0.01 & 0.03 & $0.32^{* * *}$ & $0.28 * * *$ & 0.17 & 0.01 & -0.67 & $1.98^{* * *}$ \\
\hline Romania & $0.31^{* * *}$ & $0.35^{* * *}$ & $0.35^{* *}$ & $0.27^{*}$ & 0.11 & 0.04 & -0.09 & $1.54^{* * *}$ \\
\hline Russia & $0.17^{* * *}$ & 0.05 & $0.06^{* * *}$ & $0.03^{*}$ & $0.48^{* * *}$ & 0.11 & 0.01 & $1.52^{* * *}$ \\
\hline Ukraine & $0.33^{* * *}$ & $0.24^{* * *}$ & $0.14^{* * *}$ & $0.14^{* * *}$ & $0.46^{* *}$ & $0.15^{*}$ & -0.42 & $2.16^{* * *}$ \\
\hline Africa & $0.31^{* * *}$ & $0.19^{* * *}$ & $0.16^{* * *}$ & $0.12^{* * *}$ & $0.32^{* * *}$ & $0.07^{* * *}$ & $0.24^{* * *}$ & $1.49^{* * *}$ \\
\hline Angola & $0.43^{* * *}$ & $0.23^{* * *}$ & $0.30^{*}$ & 0.11 & $-1.55^{* *}$ & -0.96 & -1.37 & -0.49 \\
\hline Botswana & $0.20 * * *$ & $0.35^{* * *}$ & $0.19^{*}$ & $0.20^{* *}$ & $0.39^{*}$ & 0.15 & 0.18 & $1.57^{* *}$ \\
\hline Burundi & $0.25^{* * *}$ & $0.36^{* *}$ & 0.14 & 0.18 & $0.99^{* * *}$ & -0.08 & 0.04 & $2.74^{* * *}$ \\
\hline Congo D.Rep. & 0.13 & 0.03 & $0.30^{*}$ & $0.31^{*}$ & 0.26 & 0.04 & 0.1 & 1.1 \\
\hline Egypt & $0.44^{* * *}$ & $0.22^{* * *}$ & $0.07 * * *$ & $0.04^{* * *}$ & $0.63^{* * *}$ & $0.20 * * *$ & $0.94^{* * *}$ & $1.91^{* * *}$ \\
\hline Ethiopia & -0.02 & $-0.15^{* * *}$ & $0.10^{* *}$ & $0.10^{*}$ & $0.66^{* *}$ & 0.12 & 0.04 & $1.76^{* * *}$ \\
\hline Ghana & $0.30^{* * *}$ & $0.23^{* * *}$ & 0.09 & 0.05 & 0.08 & 0.07 & -0.002 & 0.89 \\
\hline Guinea & $0.33^{* * *}$ & 0.13 & $0.10^{* *}$ & $0.10^{* *}$ & 0.2 & 0.03 & -0.06 & 0.75 \\
\hline Ivory Coast & $0.19^{* *}$ & 0.09 & $0.27^{* * *}$ & $0.22^{* * *}$ & - & - & - & - \\
\hline Kenya & $0.29 * * *$ & $0.22^{* * *}$ & $0.11^{* * *}$ & $0.07 * * *$ & 0.26 & 0.04 & -0.0013 & $1.93^{* * *}$ \\
\hline Madagascar & $0.19^{*}$ & 0.14 & $0.28 * * *$ & $0.27^{* *}$ & 0.21 & $0.17^{* *}$ & $1.02^{* *}$ & $1.45^{* * *}$ \\
\hline Mali & $0.20^{* *}$ & 0.1 & $0.06^{*}$ & $0.06^{*}$ & $0.34^{* *}$ & $-0.05^{* * *}$ & -0.14 & 0.42 \\
\hline Mauritius & $0.25^{* * *}$ & 0.15 & $0.25 * * *$ & $0.21^{* * *}$ & $0.52^{* *}$ & $0.40 * * *$ & $0.81^{* * *}$ & $1.85^{* * *}$ \\
\hline Morocco & $0.32^{* * *}$ & $0.30^{* *}$ & $0.19^{* * *}$ & $0.14^{* * *}$ & 0.06 & -0.0008 & $0.09^{*}$ & $1.13^{* * *}$ \\
\hline Mozambique & $0.73^{* * *}$ & $0.54^{* * *}$ & 0.34 & 0.14 & $1.14^{* * *}$ & $0.06^{* * *}$ & 0.5 & $2.91^{* * *}$ \\
\hline Namibia & $0.17^{* *}$ & $0.27^{* * *}$ & $0.34^{* * *}$ & $0.25^{* * *}$ & $0.52^{* * *}$ & 0.02 & 0.16 & $1.54^{* * *}$ \\
\hline Nigeria & $0.45^{* * *}$ & $0.17^{* * *}$ & 0.03 & 0.03 & $0.75^{* * *}$ & $0.11^{* * *}$ & 0.02 & $1.49^{* * *}$ \\
\hline Senegal & $0.33^{* * *}$ & $0.18^{* * *}$ & $0.29 * * *$ & 0.18 & $0.48^{* * *}$ & 0.06 & $0.70^{* * *}$ & $2.39 * *$ \\
\hline South Africa & $0.31^{* * *}$ & $0.06^{*}$ & $0.12^{* * *}$ & $0.10^{* *}$ & $0.36^{* * *}$ & 0.06 & $0.61^{* * *}$ & $1.45^{* * *}$ \\
\hline Tanzania & $0.33^{* * *}$ & $0.17^{*}$ & $0.22 * *$ & $0.14^{* *}$ & $0.83^{* * *}$ & $0.31^{* * *}$ & 0.06 & $2.06^{* * *}$ \\
\hline Uganda & $0.31^{* * *}$ & $0.13^{* * *}$ & $0.33^{* * *}$ & $0.30 * * *$ & $0.76^{* * *}$ & 0.02 & 0.1 & $2.26^{* * *}$ \\
\hline Zambia & $0.45^{* * *}$ & 0.18 & 0.06 & 0.09 & $0.27^{* * *}$ & 0.01 & -0.08 & $1.48^{* * *}$ \\
\hline Zimbabwe & $0.27^{* * *}$ & $0.15^{* * *}$ & $0.21^{* * *}$ & 0.03 & -0.12 & $0.10^{* *}$ & 0.01 & $1.64^{* * *}$ \\
\hline
\end{tabular}

Export premium controlling for country-industry-year interaction effects. Variables: Indicator variable for imported inputs (Column 1); Percentage of inputs that are imported (Column 2); Indicator variable for some percentage of foreign ownership (Column 3); Indicator variable for more than 50 percent of foreign ownership (Column 4); Labor productivity defined as value added per worker (Column 5); Total factor productivity estimated by OLS (CoBumn 6); Total factor productivity estimated with Ackerberg, Caves and Frazer (2015) (Column 7); Log sales (Column 8). 
Table 5

Imported Inputs and Productivity

Exporting Firms' Premium

(cont.)

\begin{tabular}{|c|c|c|c|c|c|c|c|c|}
\hline \multirow[t]{3}{*}{ Country } & \multicolumn{4}{|c|}{ Imported Inputs } & \multicolumn{3}{|c|}{ Productivity } & \multirow{3}{*}{$\begin{array}{c}\log \\
\text { sales }\end{array}$} \\
\hline & \multirow[t]{2}{*}{ importer } & \multirow{2}{*}{$\begin{array}{c}\text { share } \\
\text { imported } \\
\text { inputs }\end{array}$} & \multirow[t]{2}{*}{ foreign } & \multirow{2}{*}{$\begin{array}{c}\text { majority } \\
\text { foreign }\end{array}$} & \multirow{2}{*}{$\begin{array}{c}\text { output } \\
\text { per } \\
\text { worker }\end{array}$} & \multicolumn{2}{|c|}{ TFP } & \\
\hline & & & & & & OLS & $\mathrm{ACF}$ & \\
\hline Latin America & $0.22^{* * *}$ & $0.10^{* * *}$ & $0.16^{* * *}$ & $0.12^{* * *}$ & $0.67 * * *$ & $0.13^{* * *}$ & $0.18^{* * *}$ & $2.06^{* * *}$ \\
\hline Argentina & $0.18^{* * *}$ & $0.06^{* * *}$ & $0.20^{* * *}$ & $0.17^{* * *}$ & $0.39 * * *$ & 0.05 & $0.38^{*}$ & $1.74^{* * *}$ \\
\hline Brazil & $0.23^{* * *}$ & $0.03^{* *}$ & $0.09 * * *$ & $0.07^{* *}$ & $0.92^{* * *}$ & $0.16^{* * *}$ & $0.30 * * *$ & $2.05^{* * *}$ \\
\hline Chile & $0.41^{* * *}$ & $0.14^{* * *}$ & $0.15^{* * *}$ & $0.11^{* * *}$ & 0.52 & 0.15 & $-0.22^{*}$ & $2.05^{* * *}$ \\
\hline Colombia & $0.17^{* * *}$ & $0.06^{* * *}$ & $0.21^{* * *}$ & $0.13^{* *}$ & $0.71^{* * *}$ & 0.11 & 0.19 & $2.17^{* * *}$ \\
\hline Costa Rica & $0.40^{* * *}$ & $0.25^{* * *}$ & $0.20^{* * *}$ & $0.17^{* * *}$ & $0.85^{* * *}$ & 0.2 & 0.22 & $2.52^{* * *}$ \\
\hline Dominican Rep. & $0.28 * * *$ & $0.15^{* *}$ & $0.18^{* *}$ & $0.18^{* *}$ & 0.07 & 0.02 & -0.08 & $1.30^{* * *}$ \\
\hline Ecuador & $0.11^{* *}$ & $0.13^{* * *}$ & $0.15^{* * *}$ & $0.10^{* *}$ & 0.68 & $0.20^{* *}$ & 0.21 & $1.83^{* * *}$ \\
\hline El Salvador & $0.35^{* * *}$ & $0.27^{* * *}$ & $0.12^{* * *}$ & $0.09 * * *$ & $0.68^{* * *}$ & 0.12 & $0.63^{* * *}$ & $1.98^{* * *}$ \\
\hline Guatemala & $0.41^{* * *}$ & $0.31^{* * *}$ & $0.16^{* * *}$ & $0.14^{* * *}$ & $0.42^{* *}$ & $0.18^{* * *}$ & $0.36^{* * *}$ & $1.94^{* * *}$ \\
\hline Honduras & $0.27^{* * *}$ & $0.22^{* * *}$ & $0.20 * * *$ & 0.12 & $0.68^{* * *}$ & $0.18^{* * *}$ & $0.69^{* * *}$ & $2.36^{* * *}$ \\
\hline Jamaica & -0.08 & -0.02 & $0.22^{* * *}$ & 0.02 & $0.68^{* *}$ & 0.01 & 0.03 & $1.93^{* * *}$ \\
\hline Mexico & $0.31^{* * *}$ & $0.14^{* * *}$ & $0.18^{* * *}$ & $0.16^{* * *}$ & $0.66^{* * *}$ & 0.08 & $0.17^{* *}$ & $2.33^{* * *}$ \\
\hline Nicaragua & $0.10^{*}$ & 0.05 & $0.14^{* * *}$ & $0.12^{* * *}$ & $0.28^{* *}$ & 0.1 & $0.53^{* * *}$ & $1.31^{* * *}$ \\
\hline Panama & $0.23^{* * *}$ & $0.16^{* * *}$ & $0.13^{* * *}$ & 0.05 & 0.19 & 0.09 & 0.18 & $2.00^{* * *}$ \\
\hline Paraguay & $0.05^{*}$ & -0.06 & $0.14^{* *}$ & $0.09^{* *}$ & $0.96^{* * *}$ & 0.14 & -0.19 & $2.13^{* * *}$ \\
\hline Peru & $0.10^{* * *}$ & 0.03 & $0.19^{* * *}$ & $0.14^{* * *}$ & $0.63^{* * *}$ & 0.05 & $0.28^{* * *}$ & $1.98^{* * *}$ \\
\hline Uruguay & 0.03 & 0.07 & $0.14^{* *}$ & $0.09^{* *}$ & $0.59^{* *}$ & 0.03 & -0.26 & $1.62^{* * *}$ \\
\hline Asia & $0.31^{* * *}$ & $0.16^{* * *}$ & $0.19^{* * *}$ & $0.14^{* * *}$ & $0.54^{* * *}$ & $0.10^{* * *}$ & $0.20^{* * *}$ & $1.89^{* * *}$ \\
\hline Azerbaijan & $0.32^{* * *}$ & $0.20^{*}$ & 0.03 & -0.0023 & -0.2 & -0.13 & 0.6 & $1.40^{* * *}$ \\
\hline Bangladesh & $0.15^{* * *}$ & 0.1 & 0.03 & 0.03 & 0.06 & 0.01 & -0.01 & 0.47 \\
\hline China & $0.38^{* * *}$ & $0.13^{* * *}$ & $0.29 * * *$ & $0.20 * * *$ & & & - & $2.03^{* * *}$ \\
\hline India & $0.13^{* * *}$ & $0.06^{* * *}$ & $0.03^{* * *}$ & 0.0017 & 0.15 & $0.18^{* * *}$ & $0.20^{* *}$ & $0.88^{* * *}$ \\
\hline Indonesia & $0.53^{* * *}$ & $0.27^{* * *}$ & $0.27^{* * *}$ & $0.26^{* * *}$ & $1.35^{* * *}$ & $0.17^{* * *}$ & $0.27^{* *}$ & $4.02^{* * *}$ \\
\hline Kazakhstan & $0.51^{* * *}$ & $0.30^{* * *}$ & $0.16^{* * *}$ & 0.04 & 0.47 & & $0.76^{*}$ & $1.83^{* * *}$ \\
\hline Mongolia & 0.04 & $-0.14^{*}$ & $0.27^{* * *}$ & $0.19^{* *}$ & $1.03^{* * *}$ & 0.2 & 0.22 & $1.54^{* * *}$ \\
\hline Nepal & $0.29^{*}$ & $0.27^{* * *}$ & 0.06 & 0.03 & 0.09 & 0.06 & $-0.52^{* * *}$ & $1.93^{* * *}$ \\
\hline Pakistan & $0.15^{* * *}$ & $0.04^{*}$ & 0.02 & 0.02 & $0.66^{* * *}$ & $0.40^{* * *}$ & $0.65^{* * *}$ & $1.55^{* * *}$ \\
\hline Philippines & $0.48^{* * *}$ & $0.40^{* * *}$ & $0.38^{* * *}$ & $0.30^{* * *}$ & $0.89^{* * *}$ & 0.07 & 0.09 & $2.60^{* * *}$ \\
\hline Sri Lanka & 0.15 & 0.12 & $0.16^{* *}$ & $0.12^{* *}$ & 0.6 & $0.13^{*}$ & 0.39 & $1.28^{*}$ \\
\hline Thailand & $0.32^{* * *}$ & $0.16^{* * *}$ & $0.28^{* * *}$ & $0.15^{* *}$ & $0.68^{* * *}$ & $0.07^{* *}$ & $0.27 * * *$ & $1.77^{* * *}$ \\
\hline Uzbekistan & 0.23 & 0.05 & $0.34^{* * *}$ & -0.04 & 0.36 & 0.07 & 0.33 & $2.23^{* * *}$ \\
\hline Vietnam & $0.25^{* * *}$ & $0.14^{* * *}$ & $0.15^{* * *}$ & $0.12^{* * *}$ & $0.26^{* * *}$ & 0.11 & $0.42^{* * *}$ & $1.36^{* * *}$ \\
\hline
\end{tabular}

Export premium controlling for country-industry-year interaction effects. Variables: Indicator variable for imported inputs (Column 1); Percentage of inputs that are imported (Column 2); Indicator variable for some percentage of foreign ownership (Column 3); Indicator variable for more than 50 percent of foreign ownership (Column 4); Labor productivity defined as value added per worker (Column 5); Total factor productivity estimated by OLS (Column 6); Total factor productivity estimated with Ackerberg, Caves and Frazer (2015) (Column 7); Log sales (Column 8). 


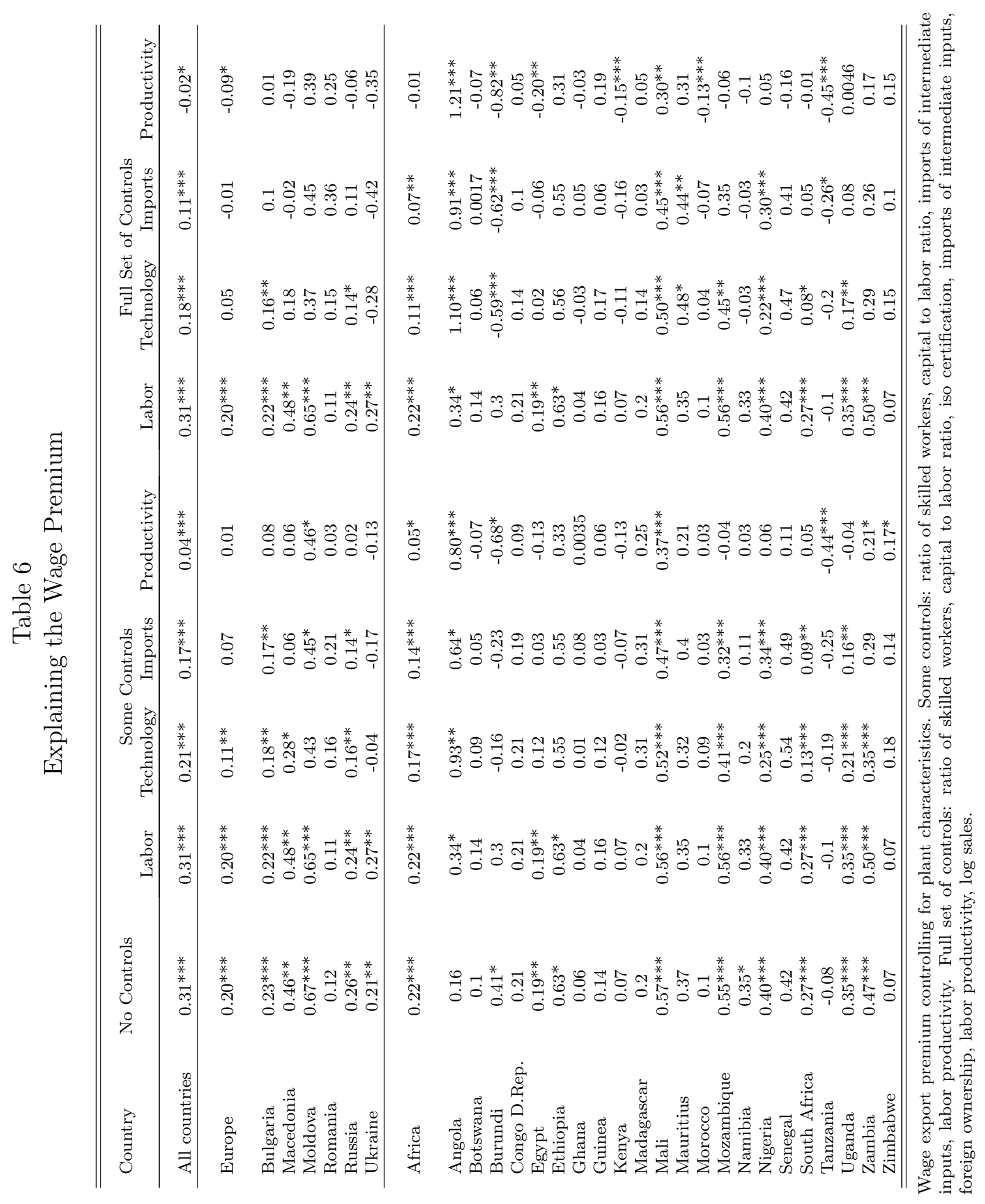




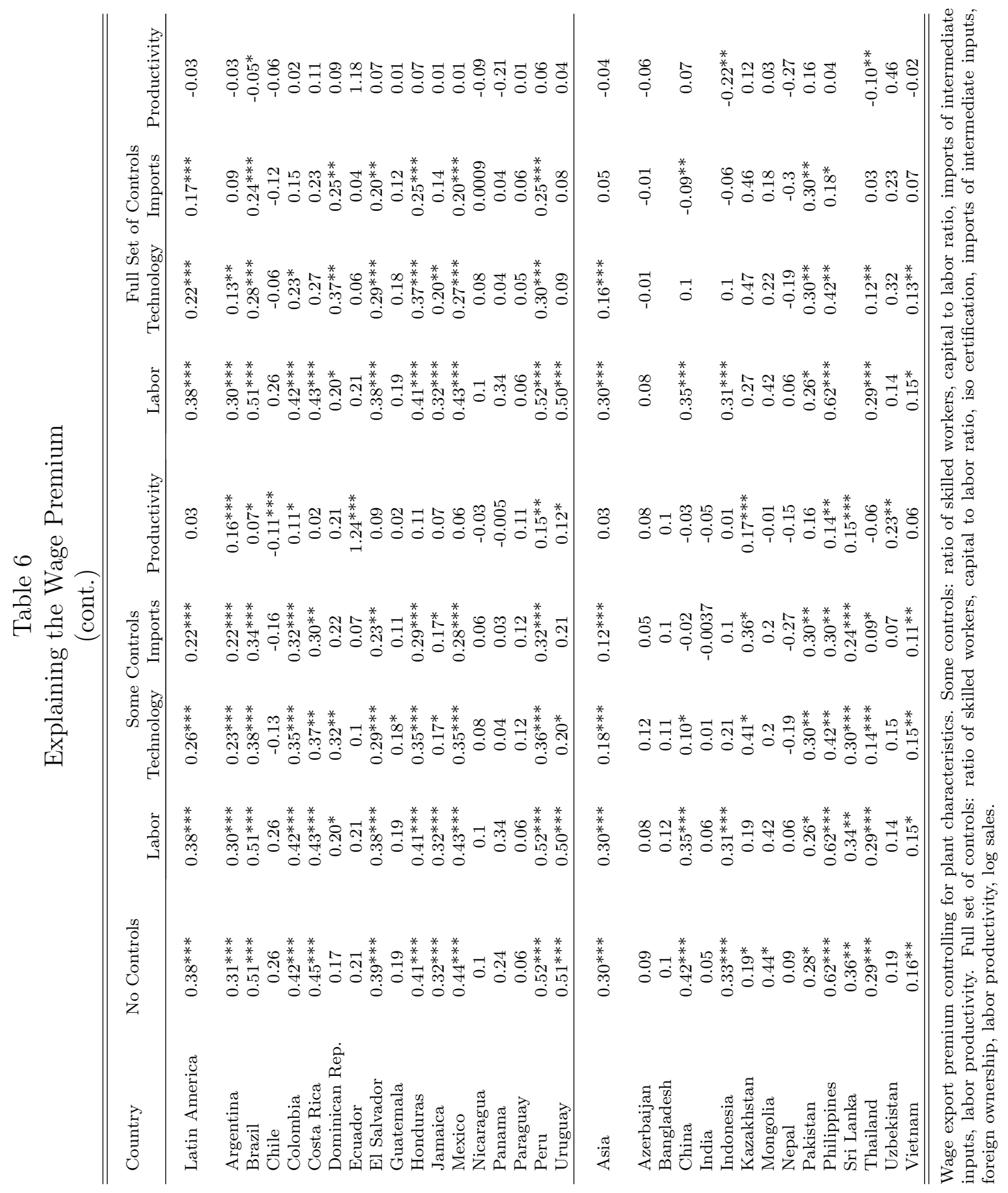


Figure 1

Optimal Firm Choices

Quality, Skills, Capital Sophistication, Material Input Quality

A) Quality $\theta$

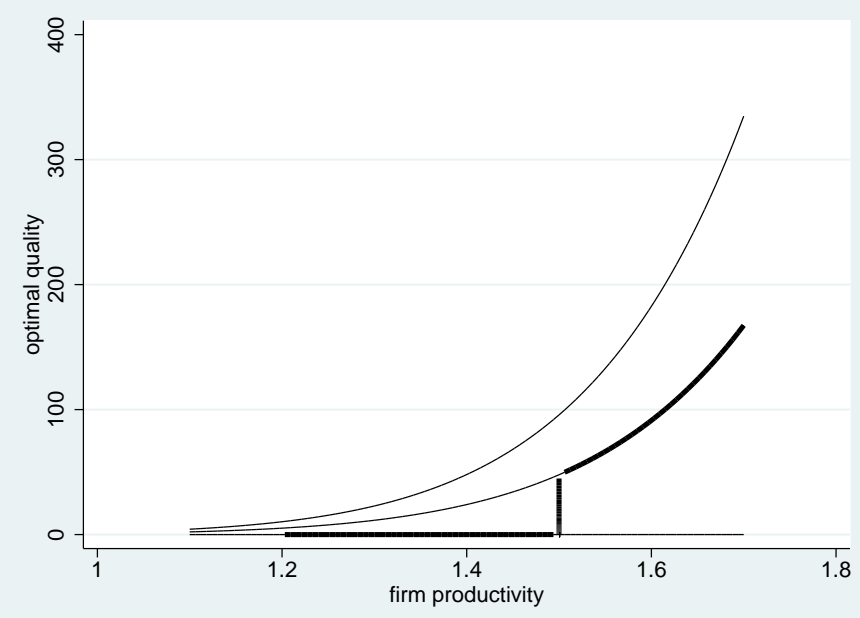

C) Capital Sophistication $K$

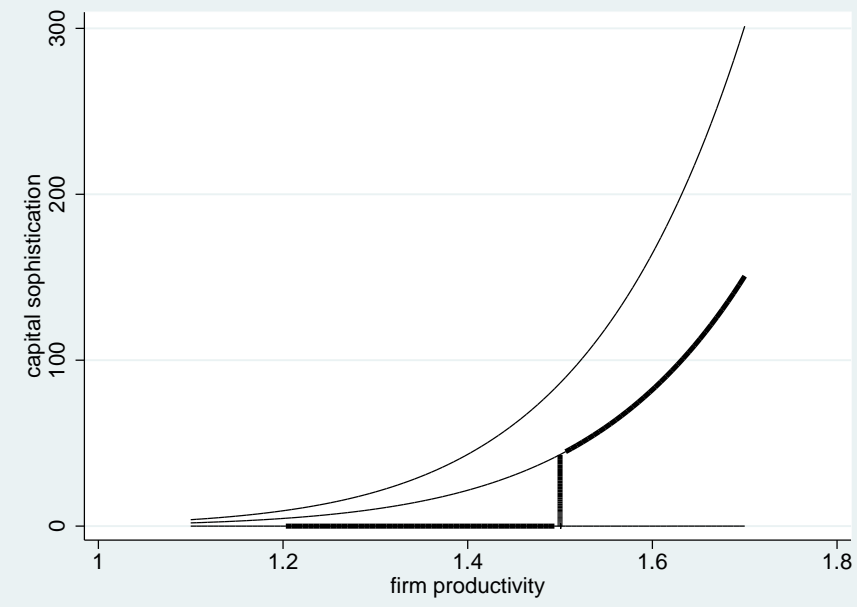

B) Skill Utilization $S$

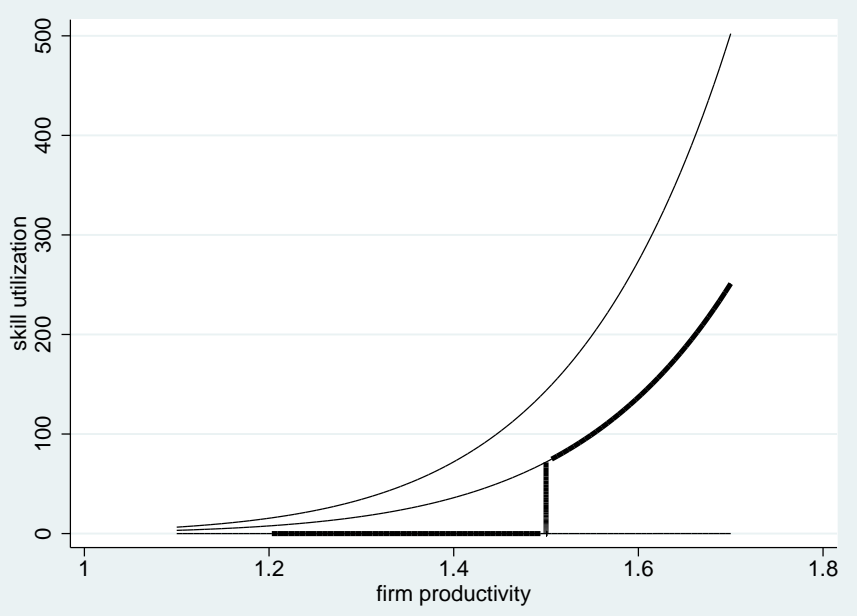

D) Material Input Quality $M$

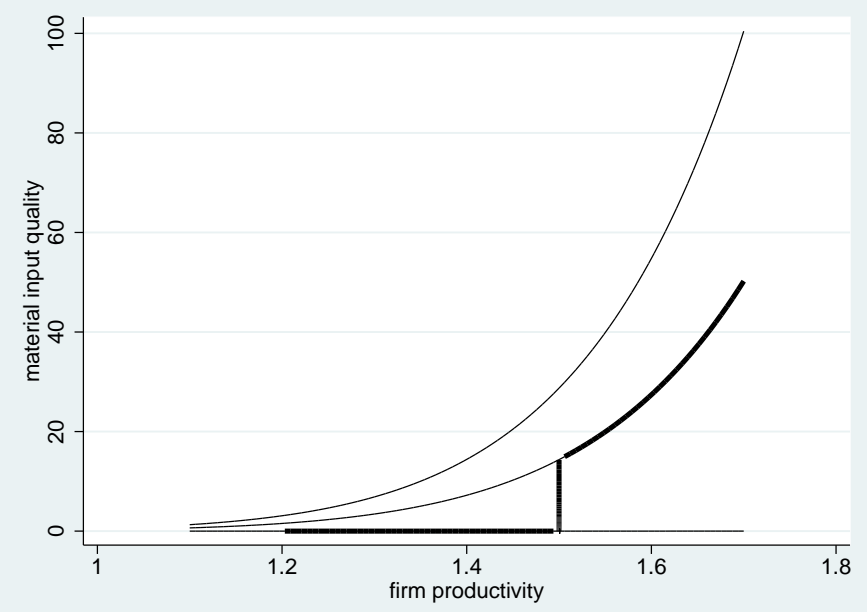

Note: Optimal quality, skill utilization, capital sophistication and input quality as a function of productivity. The solid curve represents the average for the domestic and foreign markets. Examples from a numerical solution of the model under the following parameter configuration: $\alpha=1, \sigma^{S}=0.5, \sigma^{K}=0.3, \sigma^{M}=0.1, \xi^{S}=1, \xi^{K}=1, \xi^{M}=1$. 
Figure 2

Wage Export Premia

Cross-Country Analysis

A) Skill Utilization

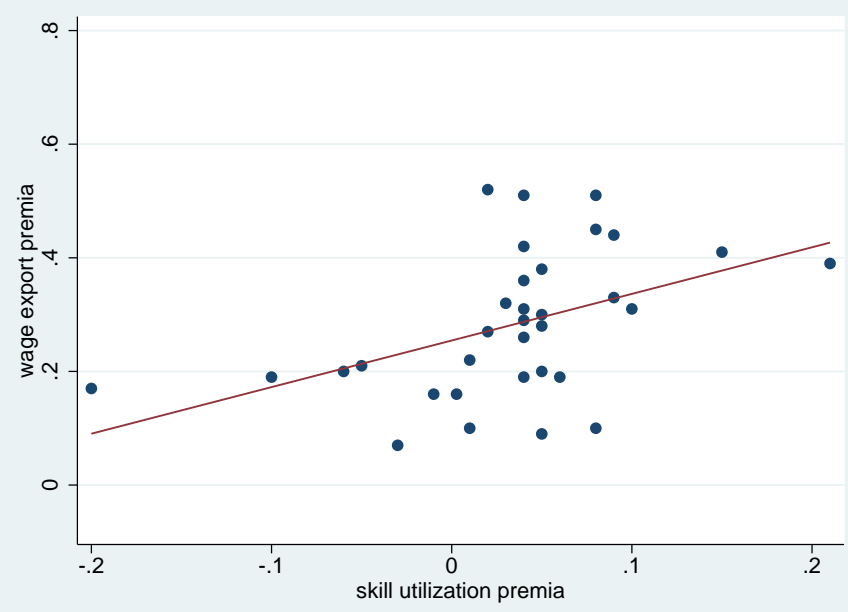

C) Imported Inputs

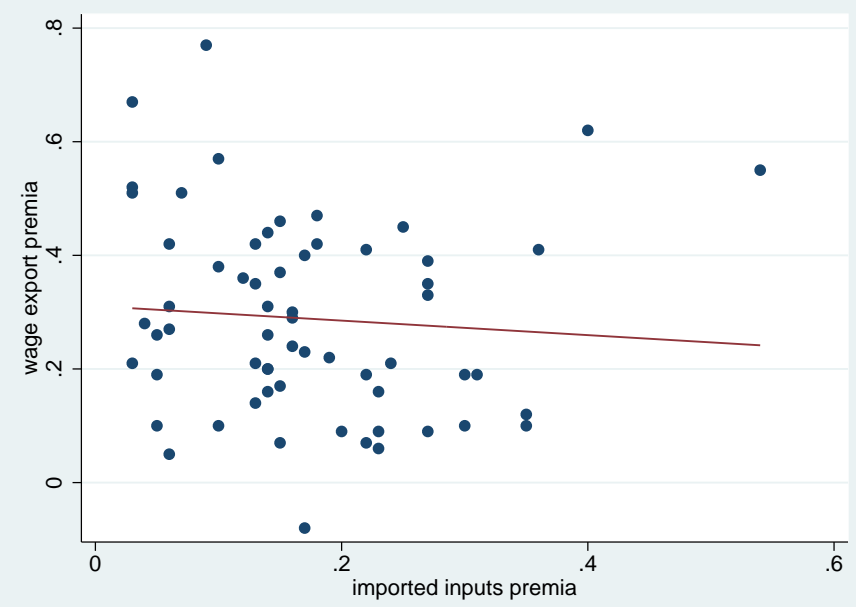

B) Machine Sophistication

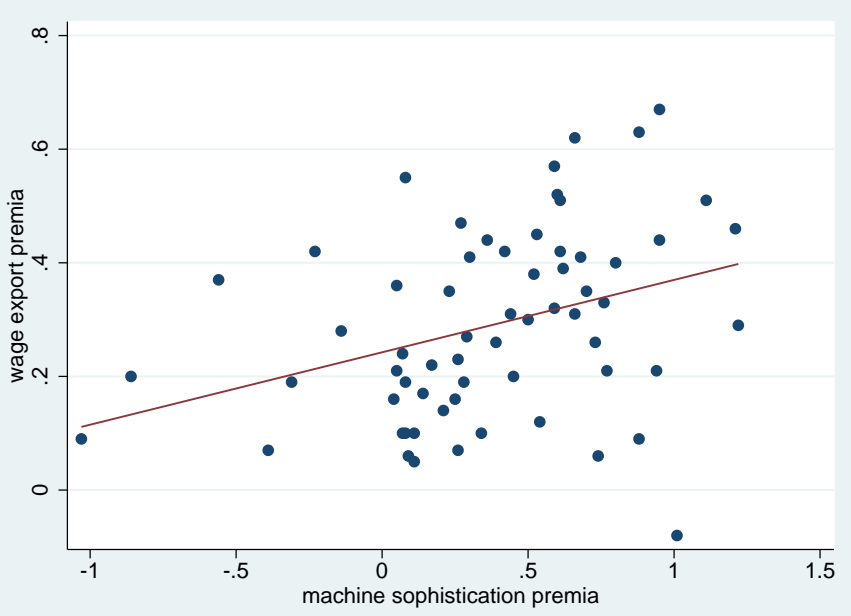

D) Technology

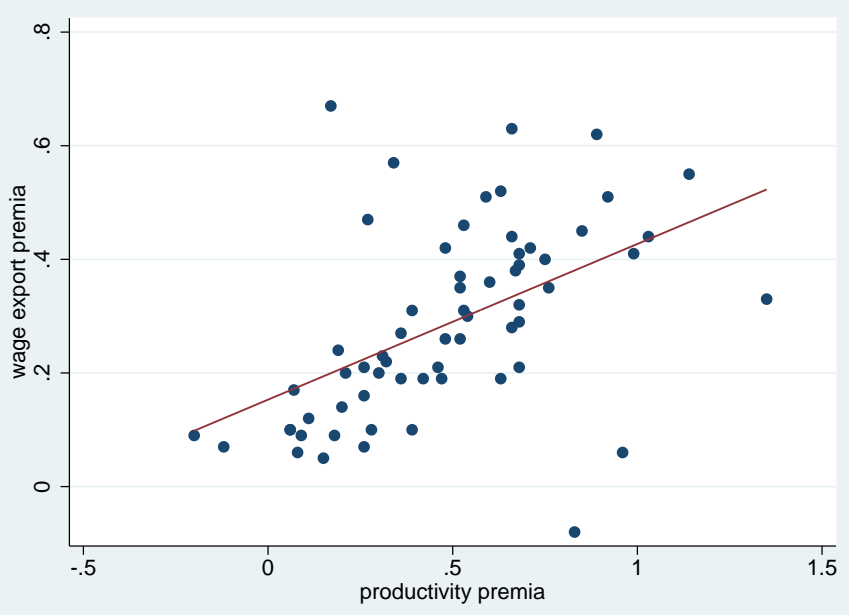

Note: cross-country scatter plots and linear fits of the export wage premia and the skill utilization premia (panel A), the machine sophistication premia (panel B), the imported inputs premia (panel C) and the productivity premia (panel D). Based on coefficients estimated in Tables 1-3. 